\title{
Engineering geological modelling for pit slope design in the porphyry copper-gold deposits of Southeast Asia
}

\author{
MJ Eggers Pells Sullivan Meynink, Australia and University of Canterbury, New Zealand
}

\begin{abstract}
Porphyry copper-gold deposits are situated in some of the most dynamic and complex geological environments, which makes engineering for open pit slope design a demanding task. The key to tackling this challenge is engineering geology, in particular understanding the key geological factors that are likely to control slope instability mechanisms in the pit wall. Engineering geology should underpin all engineering decisions throughout the investigation, modelling, analysis and design process.

Engineering geological controls can be grouped into the regional to district-scale setting of the deposit and deposit-scale factors. Knowledge of the regional setting should be summarised into a geological history that explains all elements of the model making sure the field relationships between lithology and structure are adequately described. At the deposit-scale, brecciation, alteration, weathering and structure are important elements. These processes serve to change the rock mass quality compared with the original rock due to degradation in the mechanical properties. Hydrothermal brecciation is an important mechanism for change in rock mass character while the telescoped vertical alteration zonation system typical in porphyry-style deposits can modify rock conditions particularly in areas of increased overprinting of alteration higher in the porphyry system.
\end{abstract}

Slope performance experience from operating mines in Southeast Asia strongly indicates that structurally controlled failure mechanisms operating at the inter-ramp slope scale dominant slope stability conditions. Larger scale failures involve a composite mechanism of interacting structures sometimes with a rock mass component in the centre or toe of the failure geometry. While structure is the clear primary control, rock mass condition is also a major contributor to controlling the style of movement. Antecedent rainfall is a major influence on instability signifying that drainage measures are an important component of the slope design package.

The dominance of structure in controlling slope performance is an important conclusion as geotechnical studies for pit slope design in porphyry-style deposits often focus substantially on rock mass. More attention is required in understanding the regional geological setting, how this influences district-scale features and what the controls are on deposit-scale structural patterns.

\section{Introduction}

Porphyry copper-gold deposits are amongst the deepest open pit mines and as such can be viewed as some of the greatest engineered structures in the world. Between 50 and $60 \%$ of the world's copper production comes from porphyry deposits (British Geological Survey 2007), which often carry significant secondary mineralisation in commodities such as gold, silver and molybdenum. Accordingly, porphyry copper-gold mining is an important indicator of engineering advancement and a significant contributor to the world's economy.

Porphyry deposits are distributed along convergent plate tectonic boundaries such as in the circum-Pacific region with the largest deposits found in South America, in particular Chile, which accounts for about $29 \%$ of the world's reserves (USGS 2016). Southeast Asia, situated on the southwest Pacific, contains around $6 \%$ of the worldwide identified copper resources but has an estimated $9 \%$ of the undiscovered resources (Johnson et al. 2014) making this region relatively prospective for porphyry copper. 
Convergent plate boundaries are characterised by subduction related tectonics and plutonism coupled with island arc volcanism and basin sedimentation. This generates a variable and complex geological setting at the deposit scale with multiple and overprinting geological events resulting in an apparent mirage of different lithologies, alteration types, weathering conditions and geological structures. This makes engineering challenging particularly for slope design in open pits that can be upwards of $1,000 \mathrm{~m}$ deep. Given the economic importance of these deposits, and the safety implications when slopes fail, it is vital the geological controls on slope stability are well understood in pit design.

The aim of this paper is to summarise the main elements of engineering geological modelling for pit slope design in porphyry copper-gold deposits. It is based on experience with investigation, modelling and design on projects in Southeast Asia, in particular Papua New Guinea, Indonesia and the Philippines. The fundamental premise is that the geological history of the deposit must be sufficiently understood to allow the key geological elements controlling potential slope instability mechanisms to be identified. This knowledge then feeds into how the geotechnical model should be formulated and guides selection of the most applicable analytical tools for design.

This paper reviews the relevant literature on porphyry-style deposits, outlining the typical regional and district settings and illustrates how this impacts on the deposit scale geology. The geology of porphyry deposits is examined, summarising the elements that impact on the rock mass, structure and hydrogeological components of the engineering geological model. Typical controls on critical slope instability mechanisms are illustrated with examples, which emphasise that understanding the geology is fundamental to the design of such world-class engineering structures.

\section{Geology of porphyry-style deposits}

Southeast Asia hosts world-class porphyry copper-gold deposits, including the Batu Hijau and Grasberg deposits in Indonesia; the Panguna, Frieda River, and Ok Tedi deposits in Papua New Guinea; and the Dizon, Didipio, Silangan and Tampakan deposits in the Philippines (Figure 1). Indonesia is often ranked in the top 10 countries in the world's copper production by the US mineral commodity annual surveys with the Grasberg porphyry deposit being the third largest copper producer and the world's largest producer of gold. Parts of Southeast Asia remain underexplored and in recent years new target areas have been recognised, historical mining districts continue to be explored, and new deposits are being discovered through greenfields exploration.

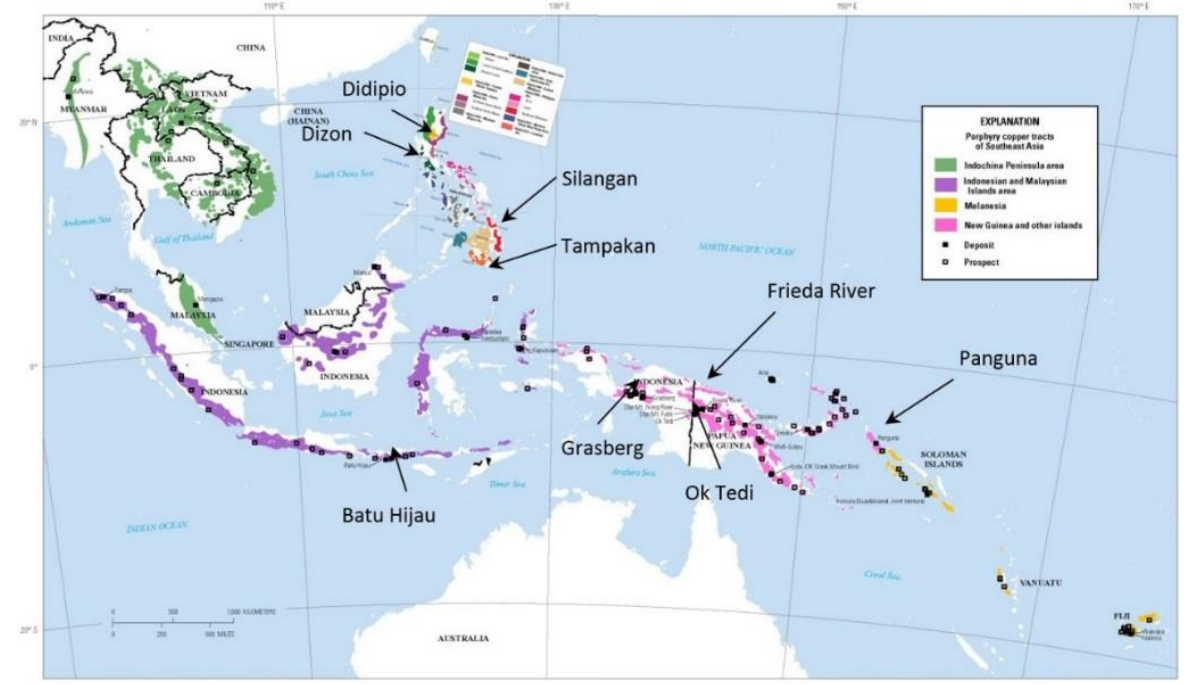

Figure 1 Porphyry copper tracts of Southeast Asia (maps from Hammarstrom et al. 2013, 2014)

Porphyry deposits derive their name due to their association with porphyritic intrusions, which are characterised by phenocryst assemblages in a fine grained matrix. Porphyry deposits form in highly active geological environments where ground conditions can be highly changeable over short distances. It is 
imperative that the controls on this variability are understood in the geotechnical model for pit slope design, which can be grouped as follows:

- Regional controls - understanding how the regional to district scale setting of the deposit influences distribution of lithologies and major structures, and the linking of these in a geological history to understand the field relationships.

- Deposit-scale controls - characteristics of porphyries that control geotechnical conditions in the pit wall rock mass, in particular brecciation, alteration, weathering and structure.

These factors are described in the following sections, highlighting the important geological conditions that contribute to the geotechnical knowledge of a deposit.

\subsection{Regional setting of porphyry-style deposits}

There is a common global setting for the distribution of porphyry deposits that tend to occur in linear, margin-parallel belts, which range in length from tens of hundreds to thousands of kilometres. Every belt contains a wide variety of geological settings producing a range of geotechnical conditions within each deposit. The mix of geological features is dependent on the relative position of the deposit within the marginal belt and the relative development of associated volcanism and sedimentation.

\subsubsection{Plate tectonics and magmatic arcs}

The global distribution of porphyry copper deposits clearly demonstrates the relationship with convergent plate boundaries. This is illustrated for Southeast Asia in Figure 2, which shows the location of some of the major porphyry copper-gold deposits relative to the Southwest Pacific tectonic setting. There is a very clear correlation of these deposits with magmatic arcs associated with the subduction (Figure 2(b)). As the subducting slab descends metamorphic dehydration takes place and the released volatiles cause partial melting of the overlying mantle. Under the influence of gravity these high temperature, low density magmas rise into the over-riding plate (Davis \& Reynolds 1996). This forms a magmatic arc with the upper reaches comprising a volcanic arc (Figure 3(a)). As such, porphyry deposits span the boundary between plutonic and volcanic environments. They occur within a broadly contractional structural regime that is characterised by crustal thickening, associated uplift and subsequent erosional unroofing, which can remove all or large portions of any related volcanic landforms. Rapid uplift and erosion under Southeast Asian tropical conditions can result in steeply incised terrain with late Cenozoic shallow marine sequences up to $1 \mathrm{~km}$ or more above current sea level, such as in the highlands of New Guinea.

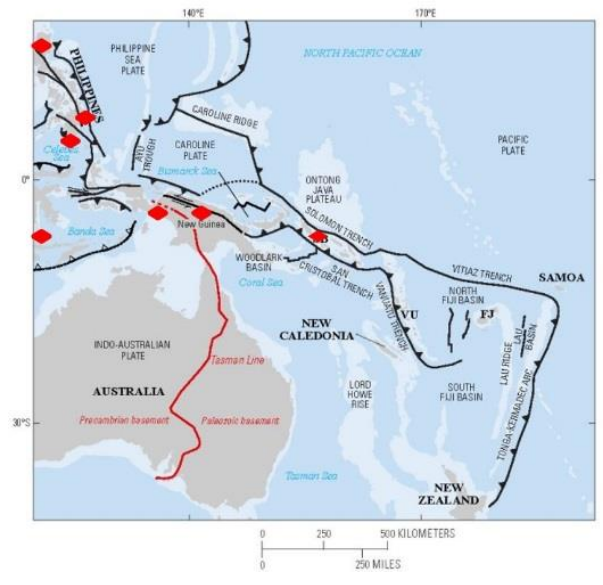

(a)

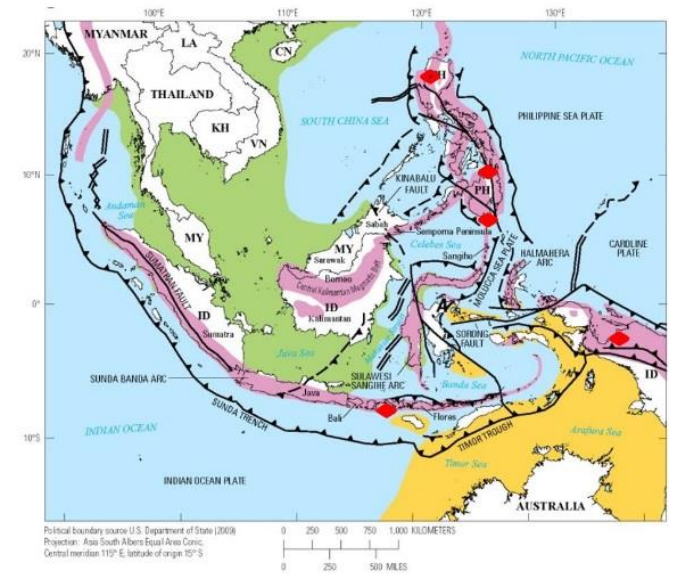

(b)

Figure 2 Regional tectonic setting of Southeast Asia showing; (a) plate boundaries and regional structures; and, (b) magmatic arcs (darkest shade) against the Australian and Eurasian continental crusts (lighter shade); taken from Hammarstrom et al. 2013, based on Hill and Hall 2003; diamond markers show approximate location of deposits labelled in Figure 1 


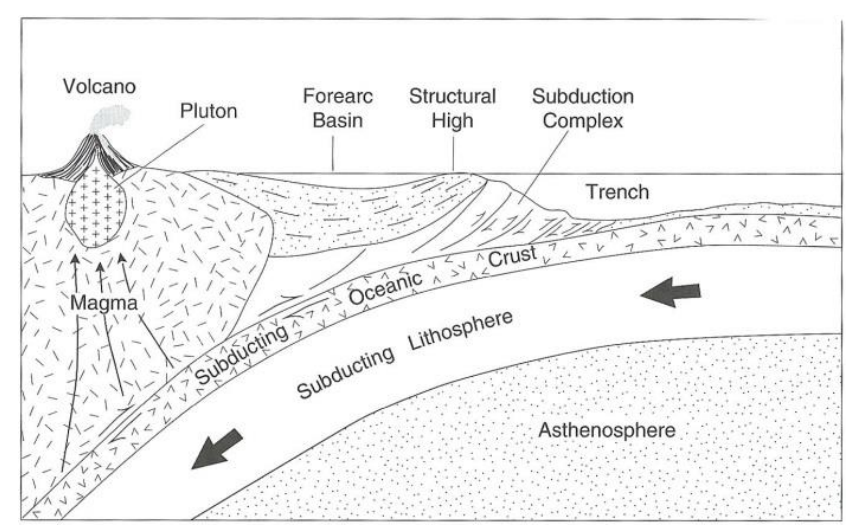

(a)

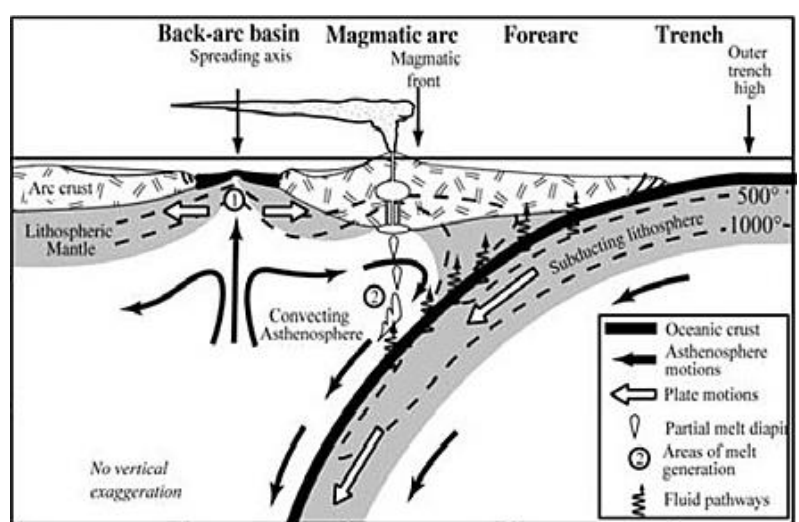

(b)

Figure 3 Generalised diagrams of subduction zones showing; (a) generation of magma and location of volcanic arc over subducting slab (Davis \& Reynolds 1996); (b) location of sedimentary basins including stretching below the back arc basin (Stern 2010)

The plutons associated with porphyry deposits are commonly of batholithic proportions and dioritic to granitic in composition. The co-magmatic volcanism is usually calc-alkaline of intermediate to felsic composition. Large stratovolcanoes can form comprising interlayered lava flows and pyroclastic deposits. These can produce aprons and fans of clastic material form on the volcanic flanks and over adjacent ground as a result of lahars, debris flows and other landslides, remnants of which can sometimes survive the rapid erosion.

Volcanic arcs are very active geological environments producing large quantities of sediment. Sediment can be transported to either side of the volcanic arc in a variety of sedimentary basins as shown in Figure 3(b). Forearc basins can contain fluvatile-deltaic, continental shelf and submarine fan deposits. Interarc basins are often filled with locally derived alluvial fan and lahar deposits together with lava flow and ashfall deposits. Backarc basins form by extensional rifting from stretching behind the arc, which accumulates a mix of sedimentary and volcanic material.

While uplift induced by collision processes and erosional unroofing can cause significant degradation of volcanic landforms, in some locations fragments of a co-magmatic andesitic stratovolcano can be preserved such as at Tampakan in the Philippines (Figure 4(a)). Volcanism can often involve extrusion of large volumes of material that cause collapse calderas to form over evacuated magma chambers such has occurred in the Silangan district in northern Mindanao in the Philippines (Figure 4(b)). This takes place post-porphyry generation when magmatic volatiles are dissipated during large pyroclastic eruptions rather than being retained and focused during earlier ore forming events (Sillitoe 2010).

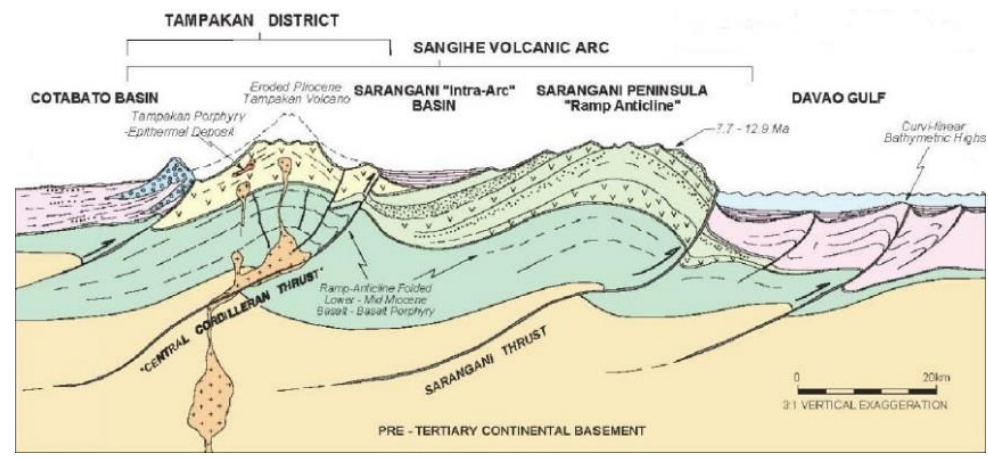

(a)

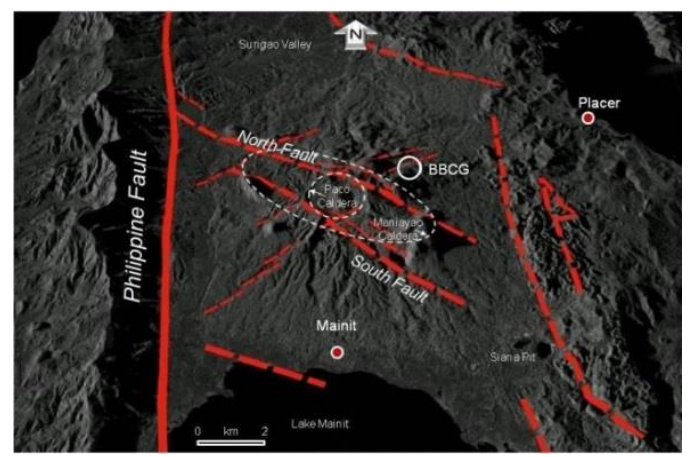

(b)

Figure 4 Examples of volcanic arc features contributing to the geological setting of porphyry deposits; (a) erosion of the stratovolcano associated with the Tampakan porphyry copper deposit in Mindanao, the Philippines (Middleton et al. 2004); (b) Paco and Maniayao calderas (white dotted lines) adjacent to the Silangan deposits (Aurelio 2010) 
In general, porphyry mineralisation can develop as two end members within the subduction system, magmatic arcs and extensional rifts (Corbett 2008). In magmatic arcs, intrusion sources for mineralisation are emplaced deep within volcanoes forming the arc while extensional rifts develop in the back arc area but can also occur as intra-arc rifts. Extensional rifts are topographic lows containing volcanism derived from more distal magmatic sources and are characterised by meteoric-dominated groundwater. Hence the geological setting is different between the magmatic arc and back arc rift environments, which can influence the controls on deposit-scale geotechnical conditions.

\subsubsection{Tectonic and structural controls}

Review of structural settings suggests there are no unique environments in which these deposits are emplaced (Tosdal \& Richards 2001). However, a long recognised negative association is that significant porphyry deposits are apparently absent from areas undergoing large-scale extensional strain. Tosdal and Richards (2001) hypothesised that deposits are most likely to form during periods of low differential (near isotropic) horizontal stress in the arc. Such conditions can form when trench retreat or advance occurs at the plate margin. Under trench retreat the tectonic setting will be extensional or transtensional, whereas, under advance, contraction or transpression occurs. This shift in the location of deformation relative to magmatism may permit the arc to approach a neutral stress state. Tosdal and Richards (2001) relate these tectonic settings to models of magma-genesis and crustal emplacement as presented in Figure 5.

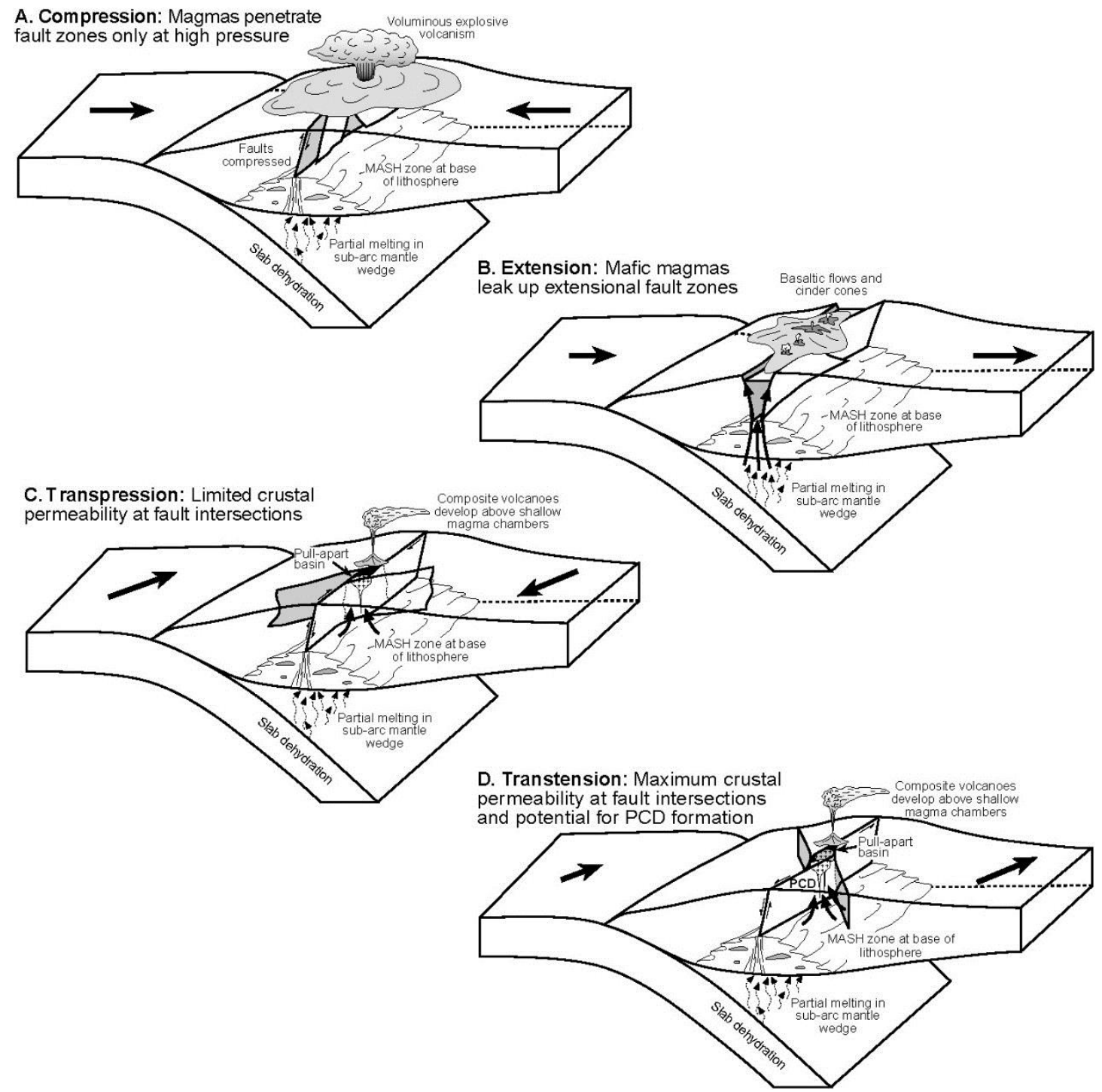

Figure 5 Relationship between convergent margin tectonics, magmatism and potential for porphyry copper development (Tosdal and Richards 2001) 
Under arc-normal compression, major arc-parallel structures will be closed restricting magma penetration into the overriding plate (Figure 5(a)). Magmas that do extrude erupt violently, which are largely unaccompanied by shallow-level plutonism.

During extension, the arc-parallel structures provide elevated permeability. This short-circuits crustal melting, allowing mantle-derived basaltic melts to be extruded rather than 'stewing' near the base of the lithosphere, melting, assimilation, storage and homogenisation (MASH), which is required to produce melts conducive to mineralisation (Figure 5(b)).

If compressive stress is locally relaxed, magma dynamics control over tectonic stress and melts ascend through the crust more passively, driven by buoyancy forces rather than magma overpressures. This allows fractionation and crustal interaction potentially generating porphyry-style deposits. Relaxation of compressive stress occurs at fault jogs or structural intersections that generate pull-apart features such as in transpressional or, more optimally, transtensional strain along arc-related structures (Figures 5(c) and 5(d)).

As such, porphyry deposits are often sited on strike-slip faults and fault intersections, in particular arc-parallel fault systems that are active before and during magmatism and mineralisation. Arc-parallel structures are steep dipping and normally separate arc segments as major sutures. Some deposits are localised on intersections with high angle transverse fault zones that may reflect underlying basement structures, which likely facilitate ascent of magma involved in porphyry systems (Sillitoe 2010).

An example of this is the Grasberg Intrusive Complex in Indonesia, which is located on a pull-part structure. This has formed along fault zones where strike-slip displacement is interrupted and transferred onto sets of normal to normal-oblique faults that define an extensional stepover to another, parallel strike-slip structure (Sapiie \& Cloos 2004), (Figure 6).
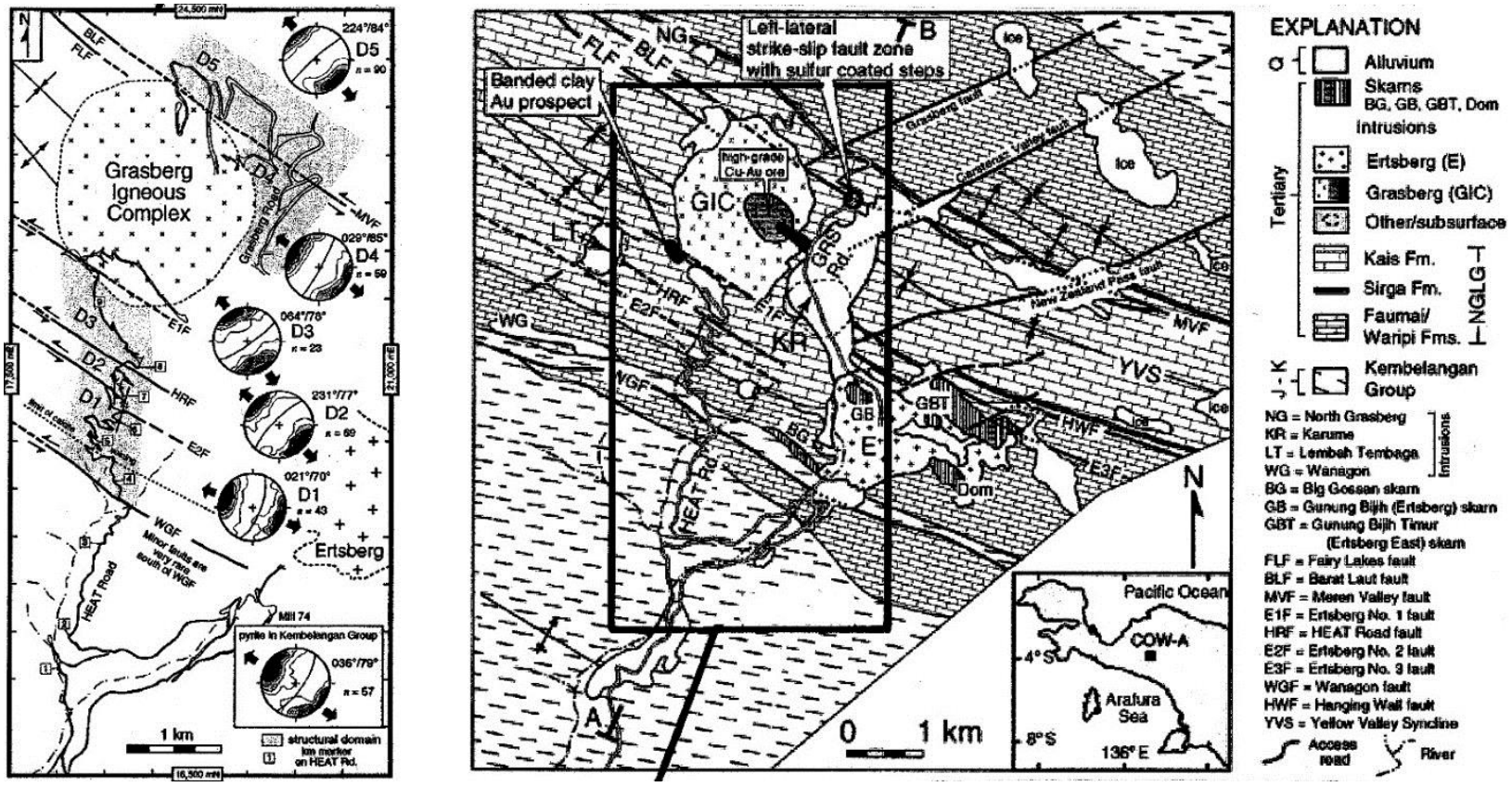

Figure 6 Extensional stepover along sinistral strike-slip faults forming a pull-part structure controlling the location of the Grasberg Intrusive Complex, West Papua, Indonesia (Sapiie \& Cloos 2004)

\subsubsection{Summary - key questions}

Influence of the regional setting on the engineering geology of a deposit can be summarised as a series of key questions, which should be addressed early in geotechnical studies. These are listed as follows:

- Where is the deposit positioned in relation to the overall convergent plate boundary model? Is it a magmatic arc or extensional rift deposit or somewhere in between? In other words, what and where are the adjacent major components of the associated subduction system (e.g. volcanic arc, 
back-arc basin, mid-arc basin, for-arc basin) in relation to the deposit location? Remember the deposit can be associated with an ancient plate boundary that may no longer be functioning or may have shifted position.

- Does the deposit have any associated volcanic and/or sedimentary materials either correlative to intrusion or post mineralisation? What does the regional picture on environment of deposition say about expected geological conditions in these volcanic and sedimentary materials?

- What is the uplift and erosional history of the deposit and how does this fit with the intrusion, mineralisation, volcanism and/or sedimentation events that may characterise the deposit? How does this knowledge help predict major elements of the engineering geological model such as paleosurfaces and unconformities?

- What is the tectonic architecture of the related subduction system? How does this control the district scale geological structures that may influence the deposit?

Overall it is important that the story of the deposit is summarised in a geological history that explains all elements of the geological model making sure the field relationships between lithology and structure are adequately described.

\subsection{Deposit-scale geological characteristics}

Porphyry copper deposits are the result of complex interactions of several geological features and processes, including (Berger et al. 2008):

- Localised copper-bearing sulphides in a network of fracture-controlled stockwork veinlets and as disseminated grains in the adjacent altered rock matrix.

- Alteration and ore mineralisation at 1-4 km depth are genetically related to magma reservoirs emplaced into the shallow crust, $6-8+\mathrm{km}$, which are predominantly intermediate to silicic in composition and located in magmatic arcs above subduction zones.

- Intrusive rock complexes emplaced immediately before porphyry deposit formation, which host the deposits, are predominantly in the form of upright-vertical cylindrical stocks and/or complexes of dykes.

- The mineralised morphology is produced by hydrothermal fluids that extensively fracture the intrusive stocks and country rock above and around the stocks.

- Zones of phyllic-argillic and marginal propylitic alteration overlap or surround a potassic alteration assemblage.

- Copper may also be introduced during overprinting phyllic-argillic alteration events.

A conceptual model by Sillitoe (2010) showing the different styles of magmatic arc porphyry and epithermal $\mathrm{Cu}-\mathrm{Au}-\mathrm{Mo}-\mathrm{Ag}$ mineralisation is presented in Figure 7. A similar model can be found in Corbett (2008). These diagrammatic representations illustrate the variety and complexity of geological processes, which can be encountered in a deposit. A primary objective of the geotechnical model for slope design is to unravel the engineering geology of this complexity to highlight the important elements that are likely to impact on slope stability. 


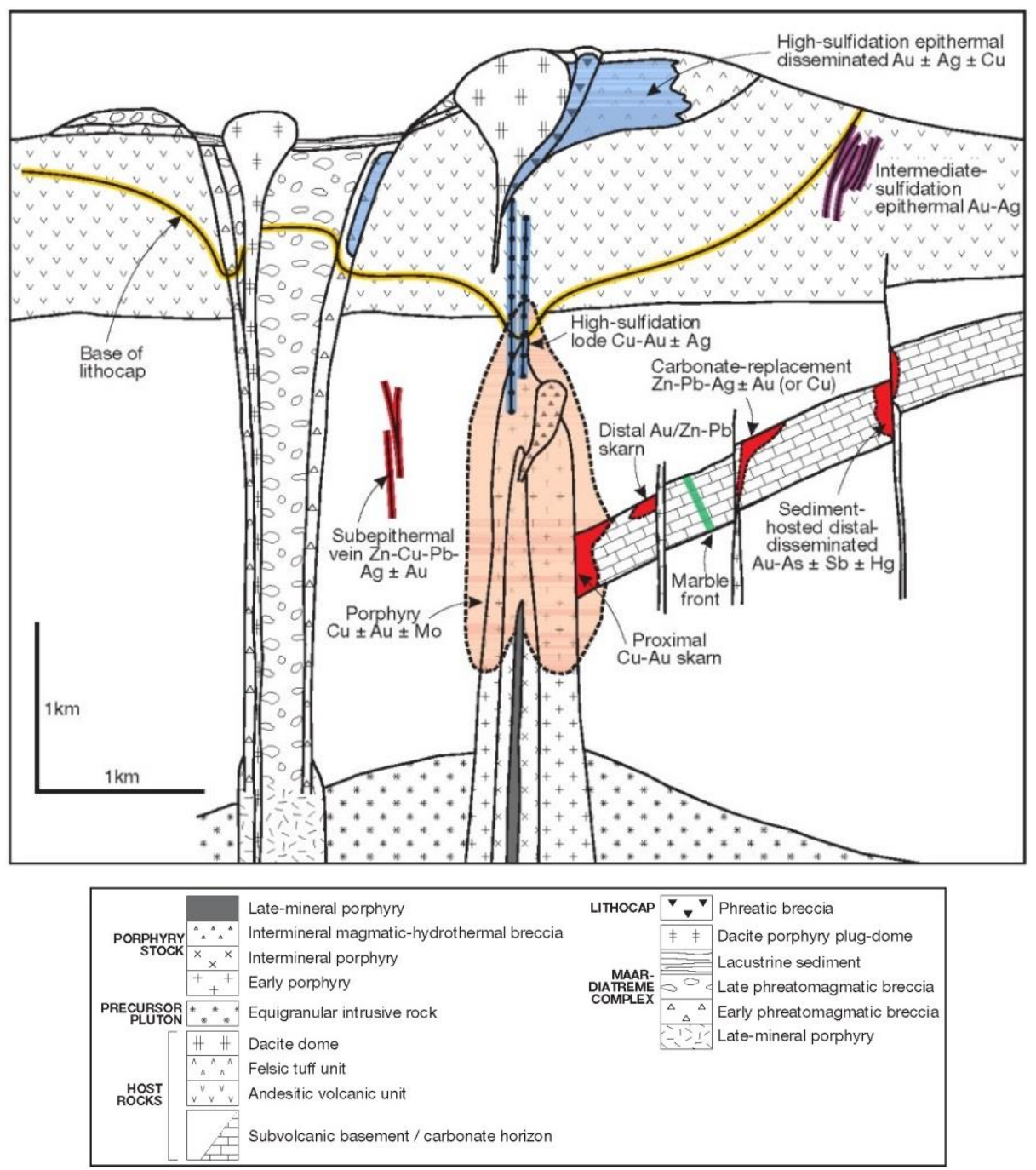

Figure 7 Diagrammatic representation of different styles of magmatic arc porphyry and epithermal Cu-Au-Mo-Ag mineralisation (Sillitoe 2010)

Within the complication of the porphyry geological model there are a number of common features that should be investigated when building the engineering geological model:

- Nature and occurrence of breccias.

- Alteration impacts on rock mass conditions.

- Weathering impacts on rock mass conditions.

- Location, orientation and nature of deposit scale structures.

These features are described in Sections 2.2 .1 to 2.2.3, while their impact on rock mass modelling is addressed in Section 3.

\subsubsection{Nature and occurrence of breccia}

Porphyry copper deposits result from the condensation of supercritical fluids derived from a crystallising magma reservoir in the shallow crust (Berger et al. 2008). Hydrothermal processes are fundamental to mineralisation events, which produce a range of rock textures from vein-dominated to breccia-dominated systems (Sillitoe 1985). This contributes to the characteristic fractured and brecciated nature of the intrusive stock and country rock in porphyry deposits. 
Breccias are important in the engineering geological model as they often represent zones of relatively poorer quality rock. Understanding the nature and distribution of breccia in open pit wall areas of the geological model is an essential component of the rock mass model. While much of the highly brecciated rocks tend to be localised inside the orebody they also occur on the limits where pit walls are positioned. Also, staged pit designs often necessitate that interim pit walls are excavated within mineralised brecciated rocks.

The complexity of porphyry geology is no better reflected than in the variety of different breccia types found in porphyry deposits. Sillitoe (1985) sub-divided the possible breccia types as listed below:

- Magmatic-hydrothermal breccia.

- Hydromagmatic-hydrothermal breccia.

- Phreatic breccia.

○ Phreatomagmatic breccia.

- Magmatic breccia.

- Volcanic breccia.

- Intrusion breccia.

- Tectonic (fault) breccia.

The primary division is based on the inferred role of magma and/or aqueous fluids in the formation of the breccia, except for tectonic breccia. Features of the main hydrothermal breccia types are summarised in Figure 8 , while some environments of breccia formation are illustrated in Figure 9 . The discussion below on breccia is based on Sillitoe (1985, 2010), Corbett and Leach (1997) and Cas et al. (2011).

\begin{tabular}{|c|c|c|c|c|c|c|c|}
\hline Type & $\begin{array}{l}\text { Position } \\
\text { in system } \\
\text { (abundance) }\end{array}$ & Form & $\begin{array}{l}\text { Relative } \\
\text { timing }\end{array}$ & Clast features & Matrix/cement & $\begin{array}{l}\text { Clast/matrix } \\
\text { proportions }\end{array}$ & $\begin{array}{l}\text { Alteration } \\
\text { types (Table 2) }\end{array}$ \\
\hline $\begin{array}{l}\text { Magmatic } \\
\text { hydrothermal }\end{array}$ & $\begin{array}{l}\text { Within porphyry } \\
\text { Cu deposits, } \\
\text { locally around } \\
\text { them (ubiquitous) }\end{array}$ & $\begin{array}{l}\text { Irregular, pipe- } \\
\text { like bodies } \\
(10 \mathrm{~s}-100 \mathrm{~s} \mathrm{~m} \\
\text { in diam) }\end{array}$ & $\begin{array}{l}\text { Typically } \\
\text { intermineral }\end{array}$ & $\begin{array}{l}\text { Commonly } \\
\text { monomict, } \\
\text { angular to } \\
\text { subrounded }\end{array}$ & $\begin{array}{l}\text { Quartz-magnetite- } \\
\text { biotite-sulfides/ } \\
\text { quartz-muscovite- } \\
\text { tourmaline- } \\
\text { sulfides } \pm \text { rock } \\
\text { flour } \pm \text { igneous } \\
\text { rock (i.e., igneous } \\
\text { breccia) }\end{array}$ & $\begin{array}{l}\text { Clast or matrix } \\
\text { supported }\end{array}$ & $\begin{array}{l}\text { Potassic } \pm \\
\text { chlorite-sericite } \\
\pm \text { sericitic; } \\
\text { uncommonly } \\
\text { advanced argillic }\end{array}$ \\
\hline $\begin{array}{l}\text { Phreatic } \\
\text { (porphyry } \\
\text { Cu level) }\end{array}$ & $\begin{array}{l}\text { Within and } \\
\text { around porphyry } \\
\text { Cu deposits } \\
\text { (relatively } \\
\text { common) }\end{array}$ & $\begin{array}{l}\text { Dikes, } \\
\text { uncommonly } \\
\text { sills and } \\
\text { irregular } \\
\text { bodies }\end{array}$ & Late & $\begin{array}{l}\text { Polymict, } \\
\text { rounded to } \\
\text { subrounded }\end{array}$ & Muddy rock flour & $\begin{array}{l}\text { Matrix } \\
\text { supported }\end{array}$ & $\begin{array}{l}\text { Sericitic, } \\
\text { advanced } \\
\text { argillic, or none }\end{array}$ \\
\hline $\begin{array}{l}\text { Phreatic } \\
\text { (epithermal level) }\end{array}$ & $\begin{array}{l}\text { Within lithocaps; } \\
\text { local surface } \\
\text { manifestations as } \\
\text { eruption breccia } \\
\text { (relatively } \\
\text { common) }\end{array}$ & $\begin{array}{l}\text { Irregular } \\
\text { bodies } \\
\text { (10s-100s m } \\
\text { in diam) }\end{array}$ & $\begin{array}{l}\text { Typically } \\
\text { intermineral } \\
\text { relative to } \\
\text { lithocap } \\
\text { development }\end{array}$ & $\begin{array}{l}\text { Commonly } \\
\text { silicified, } \\
\text { angular to } \\
\text { subrounded }\end{array}$ & $\begin{array}{l}\text { Chalcedony, } \\
\text { quartz, alunite, } \\
\text { barite, sulfides, } \\
\text { native S }\end{array}$ & $\begin{array}{l}\text { Clast or matrix } \\
\text { supported }\end{array}$ & $\begin{array}{l}\text { Advanced } \\
\text { argillic }\end{array}$ \\
\hline Phreatomagmatic & $\begin{array}{l}\text { Diatremes span } \\
\text { porphyry Cu and } \\
\text { epithermal envi- } \\
\text { ronments; surface } \\
\text { manifestations as } \\
\text { maar volcanoes } \\
\text { (present in 20\% } \\
\text { of systems) }\end{array}$ & $\begin{array}{l}\text { Kilometer- } \\
\text { scale, } \\
\text { downward- } \\
\text { narrowing } \\
\text { conduits }\end{array}$ & $\begin{array}{l}\text { Commonly } \\
\text { late, but early } \\
\text { examples } \\
\text { known }\end{array}$ & $\begin{array}{l}\text { Polymict, } \\
\text { centimeter-sized, } \\
\text { rounded, and } \\
\text { polished; } \\
\text { juvenile } \\
\text { (magma blob, } \\
\text { pumice) clasts } \\
\text { locally }\end{array}$ & $\begin{array}{l}\text { Rock flour with } \\
\text { juvenile tuff or } \\
\text { magma blob } \\
\text { component; early } \\
\text { examples cut by } \\
\text { porphyry } \mathrm{Cu} \\
\text { mineralization }\end{array}$ & $\begin{array}{l}\text { Matrix } \\
\text { dominated; } \\
\text { accretionary } \\
\text { lapilli in matrix- } \\
\text { dominated } \\
\text { layers }\end{array}$ & $\begin{array}{l}\text { None or ad- } \\
\text { vanced argillic, } \\
\text { but early } \\
\text { examples with } \\
\text { any alteration } \\
\text { type depending } \\
\text { on exposure } \\
\text { level }\end{array}$ \\
\hline
\end{tabular}

Figure 8 Features of the main hydrothermal breccia types (Sillitoe 2010) 


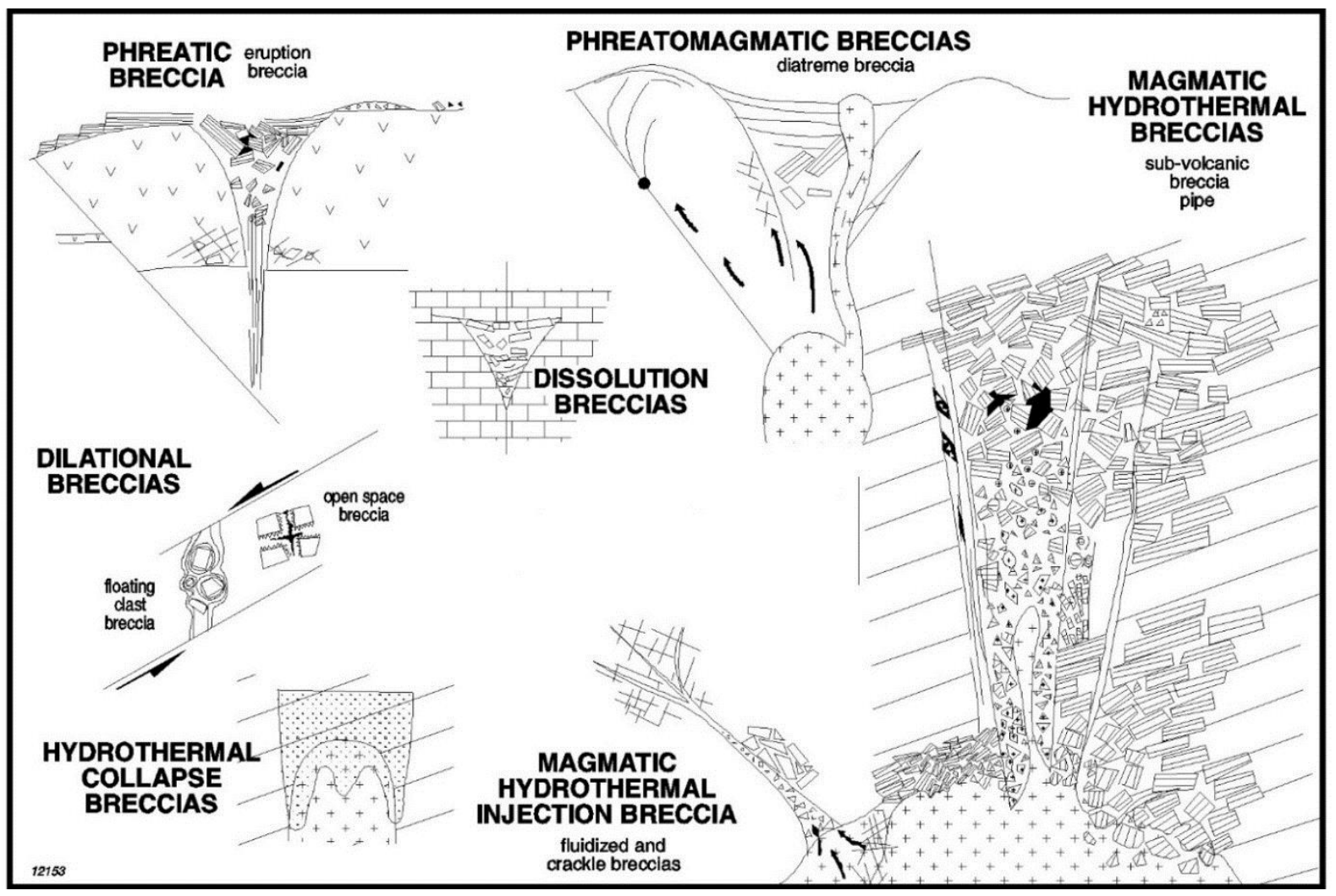

Figure 9 Breccia formation in porphyry environments (Corbett and Leach 1997)

\subsubsection{Magmatic-hydrothermal breccia}

In the deeper parts of the porphyry system the most common type is the magmatic-hydrothermal breccia (Figure 7). These are the results of sudden expulsion of fluid at pressures that exceed the rock tensile strength under lithostatic load, causing hydraulic fracturing (Burnham 1985; Sillitoe 1985). A schematic of different magmatic-hydrothermal breccia types by Corbett and Leach (1997) is shown in Figure 10. Cas et al. (2011) describe a four-step process of hydrothermal breccia generation as illustrated in Figure 11.

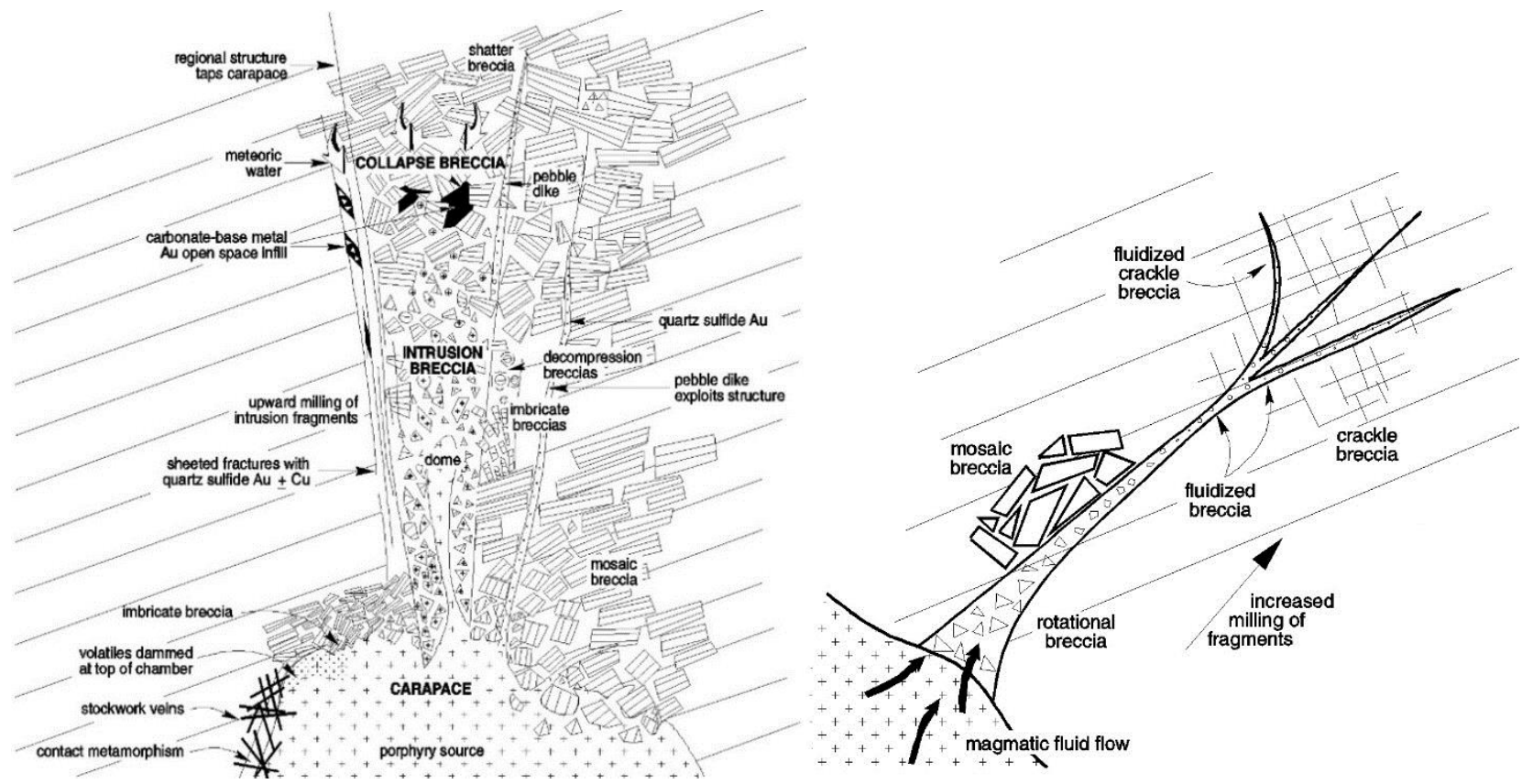

Figure 10 Magmatic-hydrothermal breccias (left) with detail of injection breccias (right), (Corbett and Leach 1997) 
Stage 1

equilibrium condition

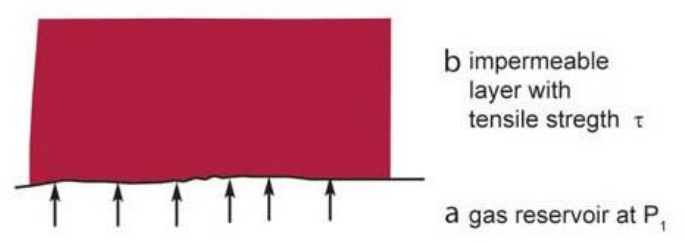

Stage 2

incipient fractures $\quad 1^{\text {st }}$ order fractures

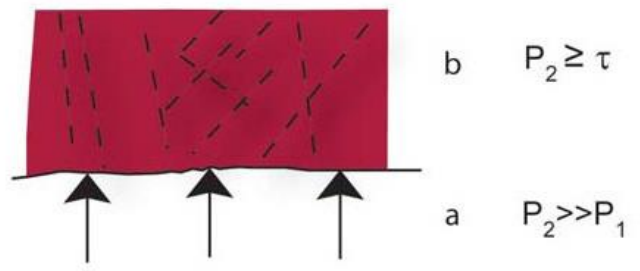

Stage 4

hydrothermal mineralization and alteration, self-sealing $2^{\text {nd }}$ and $3^{\text {rd }}$ order fractures
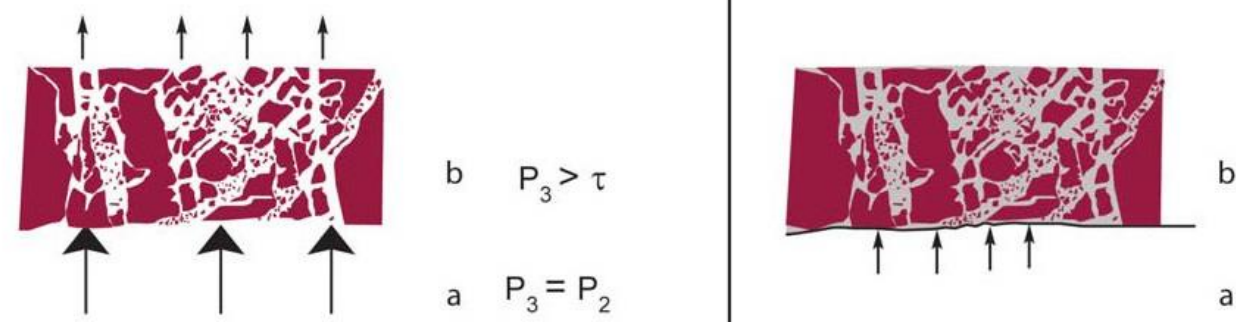

$$
\mathrm{P}_{4}<\mathrm{P}_{3}
$$

Figure 11 Four-stage model for the formation of hydrothermal breccia; $\mathrm{P}$ is fluid pressure, $\mathrm{a}$ is fluid reservoir, b is rock (Cas et al. 2011)

The resulting catastrophic fragmentation of the host rocks propagate upwards from the source towards areas of reduced effective mean stress. This forms lensoid, ovoid or irregular pipe-like geometries. In contrast to hydromagmatic breccia, they are normally blind and do not penetrate the overlying epithermal environment while downwards they can fade away due to increased clast/matrix ratios.

Many deposits only contain minor volumes of magmatic-hydrothermal breccia (say, 5-10\%), but deposits can range from being breccia free to breccia dominated. This breccia type shows a variety of textures (Figure 8) depending on clast form and composition, clast/matrix ratio and matrix/cement type.

\subsubsection{Hydromagmatic breccia}

Hydromagmatic breccia is generated by the interaction of magma and an external source of water such as ground or surface water. Under the Sillitoe sub-division phreatomagmatic breccia occurs where both water and magma directly contribute to its formation, whereas, phreatic breccia is produced when only magmatic heat had access to the external water source.

Phreatic breccia is widely seen in porphyry systems often resulting from:

- Flashing of relatively cool groundwater on approach to magma forming dyke or large bodies with pebble-sized clasts.

- Vapour pressure build-up beneath impermeable layers forming steep, tabular or irregular bodies.

Phreatic breccia normally has polymictic clasts set in a muddy rock flour matrix (Figure 8).

Diatremes produce phreatomagmatic breccia, which are concentrated towards the upper reaches of the porphyry system and typically vented to the paleosurface (Figure 7). They often have a distinctive texture where widely spaced, centimetre sized clasts are dominated by a rock flour matrix (Figure 8). They can be poorly lithified, friable and clay rich. Many diatremes are late stage features in the porphyry system; however, when they form early (e.g. Grasberg and Silangan) they can act as receptive rocks to the main alteration and mineralisation and become annealed. 


\subsubsection{Magmatic, intrusion and tectonic breccias}

Magmatic breccia forms where there is little mixing of meteoric waters. The term diatreme is often used to describe vents that contain magmatic breccia but it is distinct from phreatomagmatic breccia.

Volcanic breccia results from fragmentation and eruption of magma in subaerial environments.

Intrusion breccia is a direct product of the passive sub-surface movement of magma. They occur as irregular patches near the walls and roof of sub-volcanic stocks.

Tectonic breccia results from brittle fracture at high strain rates during fault movement. They vary from milled puggy material to crush breccia. In contrast to the hydrothermal breccia types, intrusion and tectonic breccia are normally generated without fluid movement.

\subsubsection{Alteration zones and supergene weathering}

Hypogene (bottom-up) alteration in porphyry deposits is normally classified according to mineral assemblages, which are grouped in categories. Due to multiple and overlapping pulses of hydrothermal fluid flow, each sequential fluid pulse may contact previously altered rock. Despite this intrinsic complexity a similar general zoning of alteration categories is evident in most deposits. A simple conceptual model of the lateral and vertical relationship was first proposed by Lowell (1968), and Lowell and Guilbert (1970), as shown in Figure 12(a). Sillitoe's 2010 version of the generalised alteration zoning pattern is presented in Figure 12(b), which uses the same conceptual outline as Figure 7(b).

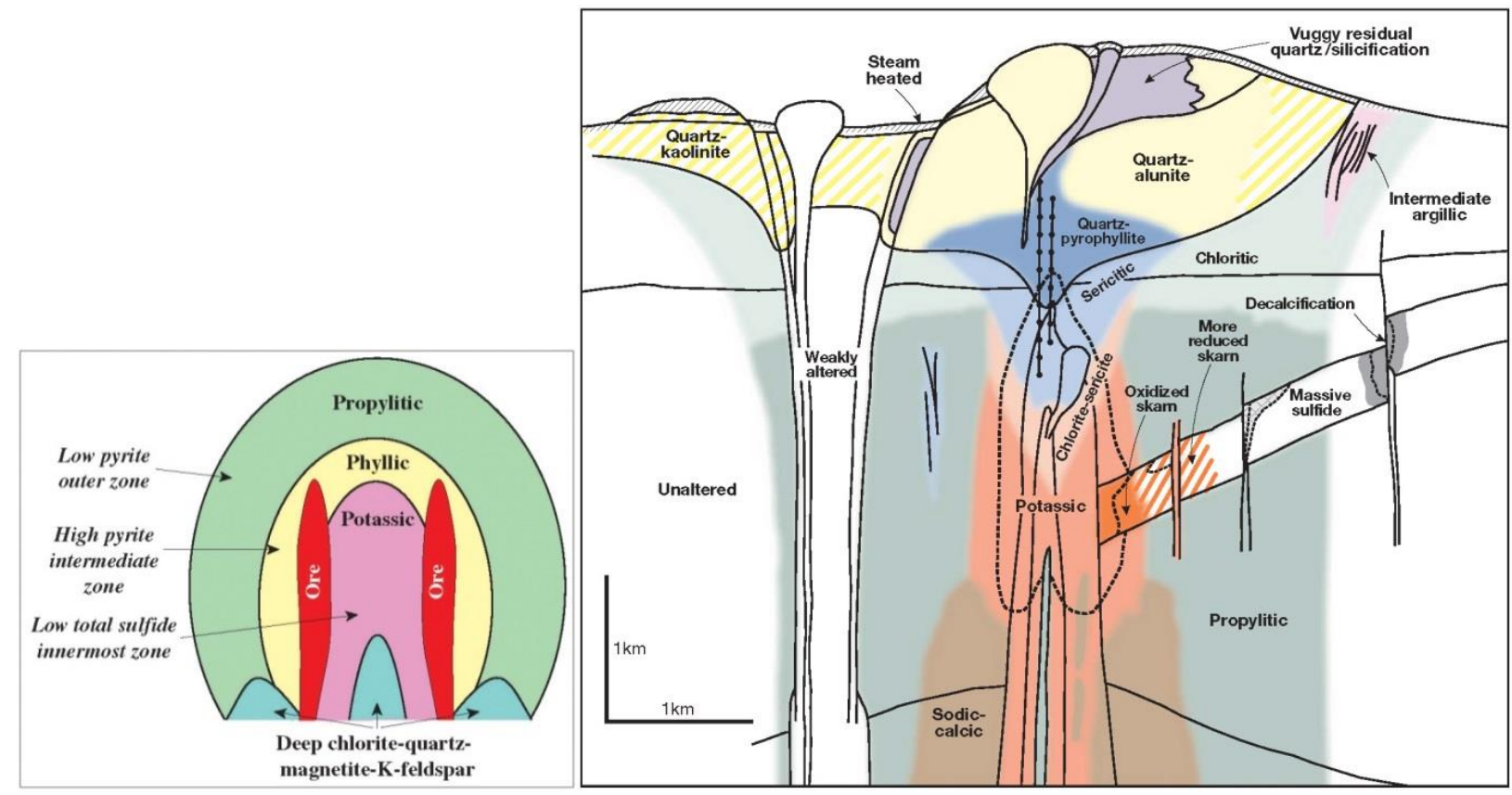

(a)

(b)

Figure 12 Generalised alteration zonation patterns in porphyry deposits; (a) idealised scheme after Lowell and Guilbert 1970 (Berger et al. 2008); and, (b) zoning pattern for a telescoped deposit (Sillitoe 2010)

At the beginning of deposit development, two distinct zones form. In the core of the upflow zone of magmatic fluids, potassic alteration occurs. The thermal gradient associated with this high temperature upflow zone leads to convection of surrounding groundwater that result in generation of a peripheral propylitic alteration zone. Phyllic (sericitic) alteration is normally seen to crosscut and form a shell or 'halo' around potassic alteration, which develops from a mixture of meteoric and magmatic fluids. The boundary zone between phyllic and potassic alteration is often associated with significant mineralisation (Tosdal and Richards 2001), but phyllic alteration is not distinct in all deposits (Berger et al. 2008). 
Clay-rich alteration assemblages such as argillic and advanced argillic commonly occur above the core of the deposit and laterally along the margins of the system. This is sometimes referred to as the lithocap (Figure 12(b)). They are relatively porous and permeable and can host epithermal mineralisation.

In general the alteration types become progressively younger upward such that the shallower alteration zones overprint and partly reconstitute deeper types. The vertical distribution of alteration types depends on the degree of over-printing or telescoping (Sillitoe 2010).

Weathering due to infiltration of meteoric water can lead to oxidation and leaching of primary mineralisation. This produces zones of supergene (top-down) enrichment near the base of the weathered zone. This process overprints the upper levels of the porphyry system adjacent to the present-day ground surface or below an ancient ground surface, which has subsequently been buried as a paleosurface.

\subsubsection{Deposit-scale structure}

Deposit-scale geological structure typically involves multiple phases of deformation characterised by at least several fault and shear sets overprinted by a complex system of jointing. Resolving the deposit scale geological structure is an essential task when building the engineering geological model as structure normally plays a fundamental role in controlling failure mechanisms in large porphyry pit walls, as discussed in Section 4.

Deposit-scale structure is typically controlled by two associations:

- Regional structure.

- Intrusion-related structure.

\subsubsection{Regional structural association}

The regional setting for many porphyry deposits is characterised by strike-slip faulting as explained in Section 2.2.1. In particular, mineralisation occurs at fault jogs or structural intersections, which generate pull-apart features such as in transpressional and transtensional settings along arc-related structures (Figures 5(c) and 5(d)).

A model of pull-apart basins is shown in Figure 13 based on a dextral side stepping fault (Wu et al. 2009). This model differentiates between pure strike-slip, where the relative motion is parallel to strike-slip faulting, and transtensional, where movement is oblique and divergent to faulting.

a Pure strike-slip pull-apart basin
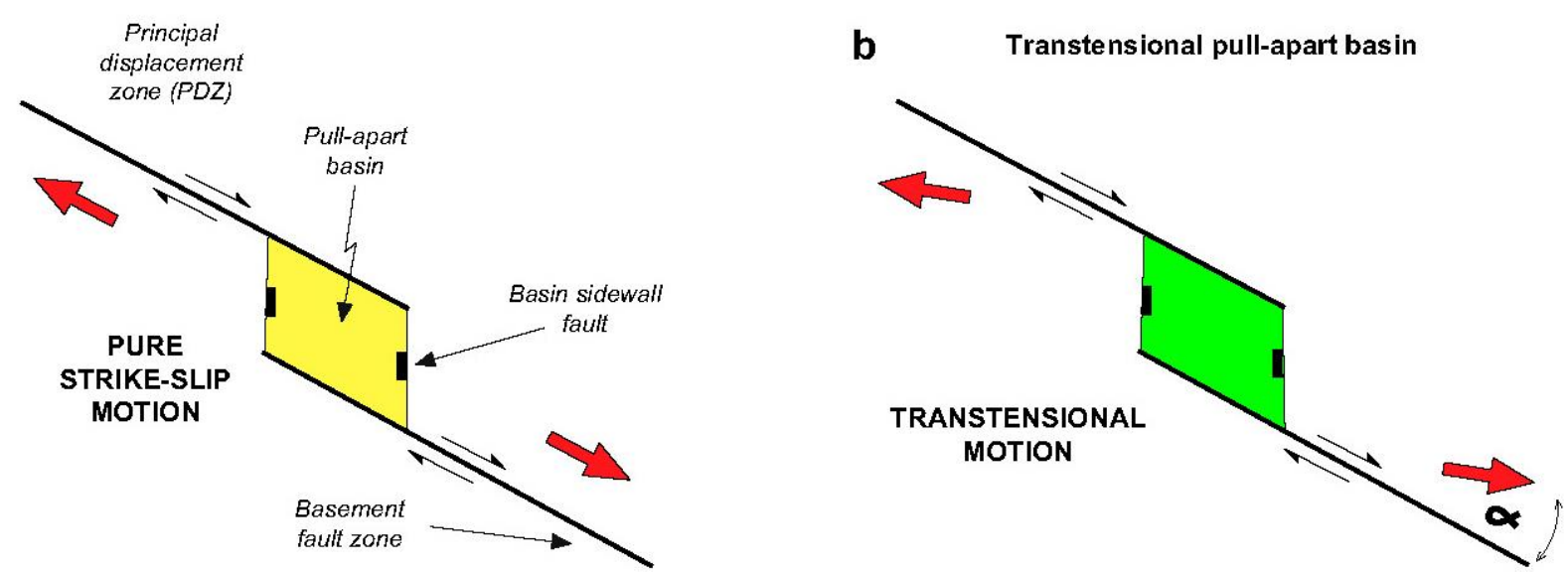

Figure 13 Geometric layout of a pull-apart basin on a dextral side stepping fault system; the pull-apart basin is defined to develop in pure strike-slip when $\alpha=0^{\circ}$ and in transtension when $0^{\circ}<\alpha \leq 45^{\circ}$ (Wu et al. 2009) 
Plan and three-dimensional (3D) views of the expected fault styles in a dextral strike-slip model are shown in Figure 14. Under pure strike-slip a system of near-parallel or terraced normal faults are generated oblique to the strike-slip direction. In a genuine transtensional setting a series of normal faults is arranged in an en-echelon pattern. A block model showing the en-echelon faulting on the edges of the transtensional pull-apart basin is provided in Figure 14.
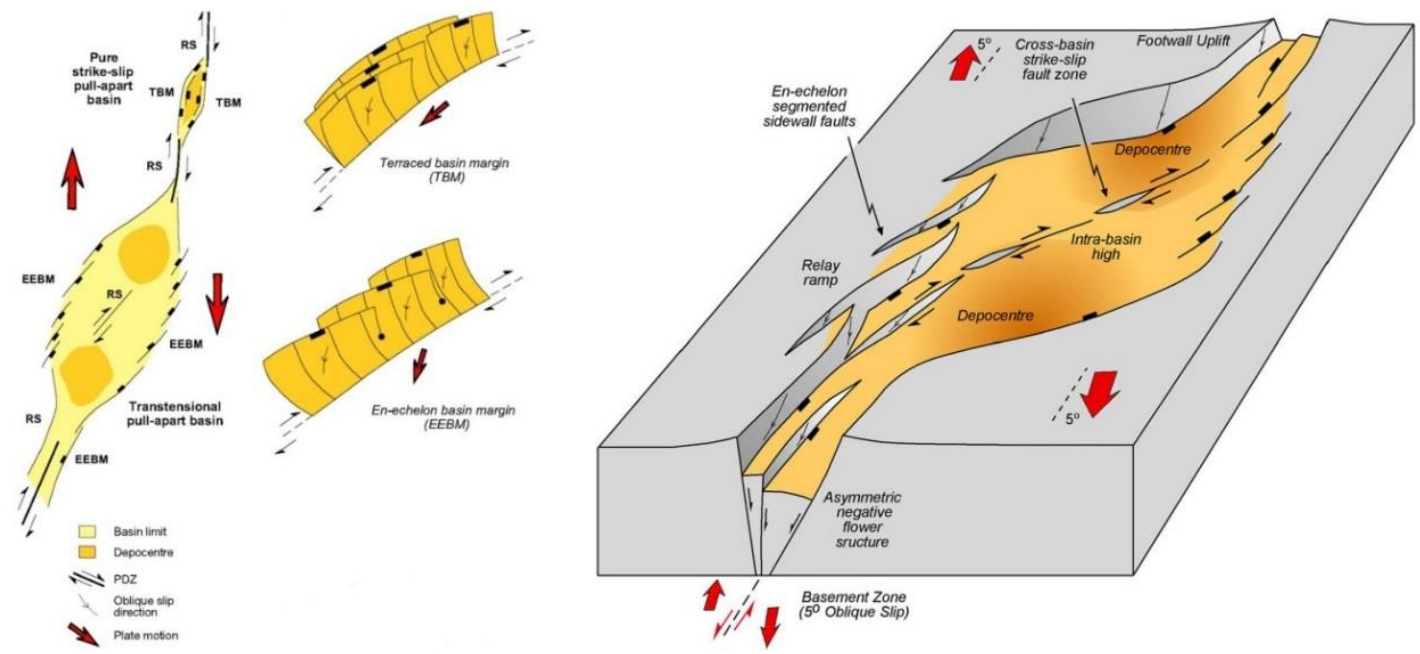

Figure 14 Fault styles associated with pure strike-slip (top left) and transtensional (bottom left) pull-apart basin systems in plan view and 3D; block model of transtensional system (right), (Wu et al. 2009)

Degree of evolution of the pull-apart basin controls the relative development of the associated structures. In the earlier stages, en-echelon normal faults defining the edge of the basin are relatively steep and planar in shape (Figure 15(a)). On further deformation these faults become curved with a concave-up form and are less steep. Relay ramps develop linking en-echelon structures and a cross-basin fault zone can form comprising discontinuous strike-slip fault segments (Figure 15(b)).

a

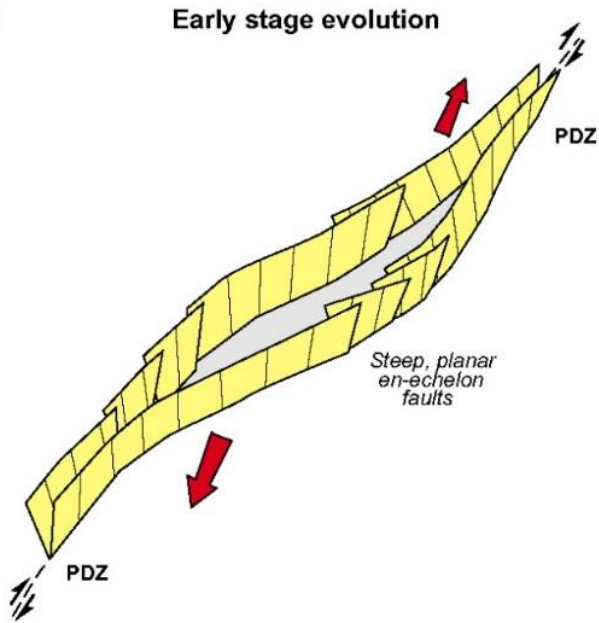

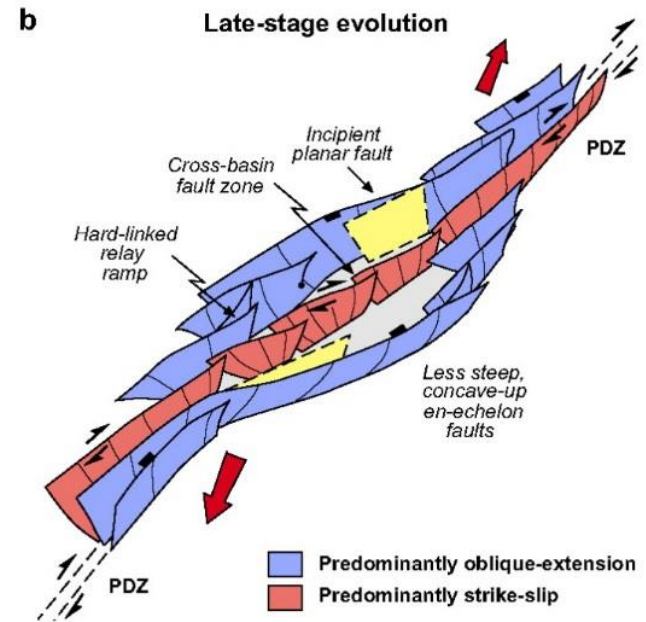

Figure 15 Evolution of a transtensional pull-apart basin showing the pattern of associated structures and how they change with increasing maturity of the basin (Wu et al. 2009)

This is a relatively sophisticated theoretical model, which is useful in interpreting and unravelling the pattern of major structures seen at the deposit scale. Similar models can be found in the literature for transpressional settings, however, experience suggests that transtensional architecture is more frequent for porphyry deposits in Southeast Asia.

In some deposits a Riedel shear pattern can develop in response to strike-slip movement along the district scale faults controlling the deposit placement. This pattern usually presents as a secondary set of shears 
that are superimposed over the pull-apart related structures, where present. Interpretation of a Riedel pattern is based on geometric relationships as per published models (Figure 16) and field observations of displacement indicators where exposures allow adequate mapping.
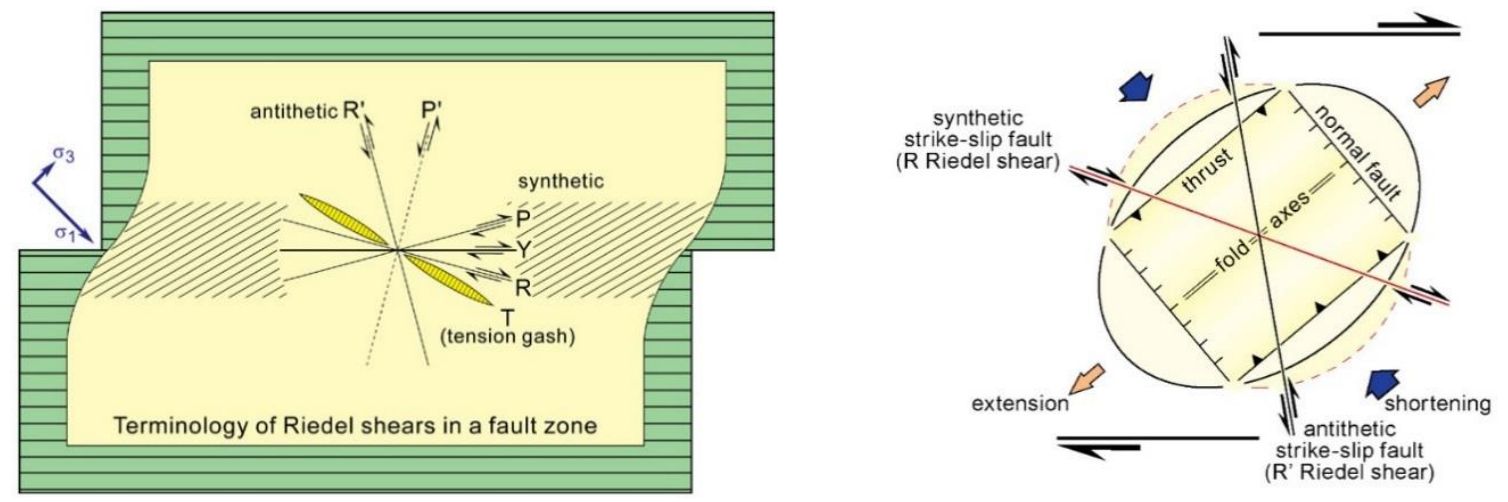

Figure 16 Riedel shear model for dextral (right lateral) strike slip movement (Burg 2015)

\subsubsection{Intrusion related structure}

Various models have been proposed to explain the growth mechanisms of a magma chamber. A preferred explanation suggests magma ascension stops where the magma becomes capable of deforming or displacing the wall rocks (de Saint Blanquat et al. 1998). At high crustal levels where porphyry stocks are sourced, magma chambers grow by roof lifting due to either 'piston' or cantilever mechanisms (Cruden 1998), as shown in Figure 17. To accommodate extension in the roof rocks steep faults can develop at elevations where the porphyry stocks are intruded. A sequence of faults may develop, nucleated at the lateral tip of the expanding chamber. Alternatively, extension of the roof rocks may be assisted by reactivation of pre-existing faults such as the structures associated with a pull-apart basin hosting the intrusion.

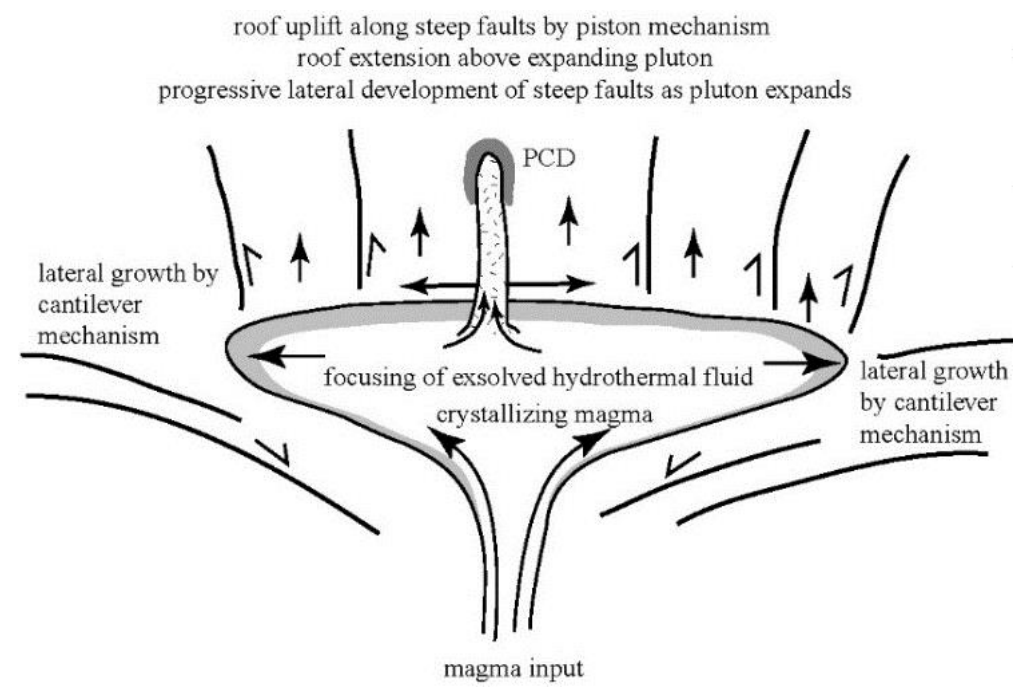

Figure 17 Model for growth of a tabular magma chamber feeding a porphyry copper deposit (PCD) illustrating the potential for steep faults in the roof rocks extending to similar elevations of the mineralisation (Tosdal and Richards 2001)

At the deposit scale, brittle deformation associated with emplacement of the host intrusive rocks can take the form of concentric and radial joint patterns at relatively shallow levels centred on the stock (Figure 18). The outermost, early stage intrusive rocks are stretched as a result of inflating the central part by later intrusive events. The stretching effect causes radial expansion and the formation of sub-vertical radial joints. Inclined, concentrically oriented joints are interpreted to form during relaxation and/or caldera-type collapse as the magma chamber at depth becomes depleted. These patterns form in the intruding stock and can also be present in the adjacent country rock. 

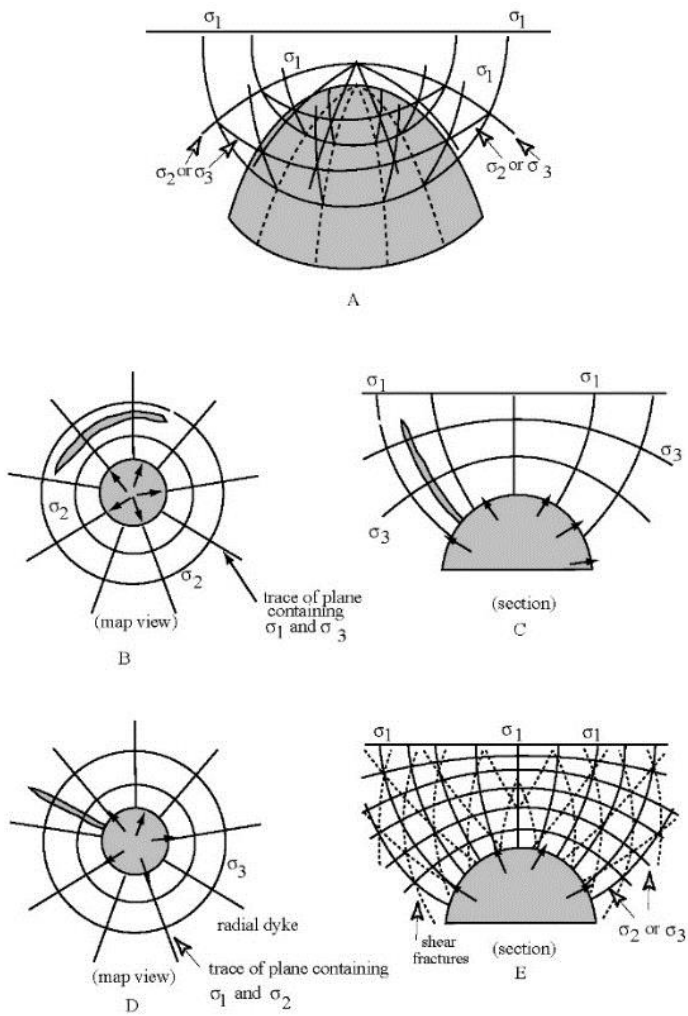

Figure 18 Stress trajectories and formation of concentric-radial joints in shallow level cylindrical stock; (A) stress trajectories; (B), (C) map and section of concentric or sheet joints; (D) map of radial joints; $(E)$ section showing orientation of shears that can develop due to the intrusive stress system (Tosdal \& Richards 2001)

In the host rocks, structure that existed prior to intrusion can influence the concentric-radial pattern of jointing by changing the stress distribution and providing favourably oriented planes of weakness. If there are multiple centres, as in some large deposits, the patterns can overlap (Figure 19 (a)) and the quasi-concentric system can become more elliptical reflecting the shape of the stock. At deeper levels in porphyry systems, jointing is often more linear with the direction controlled by the orientation of feeder dykes (Tosdal and Richards 2001), (Figure 19 (b)).

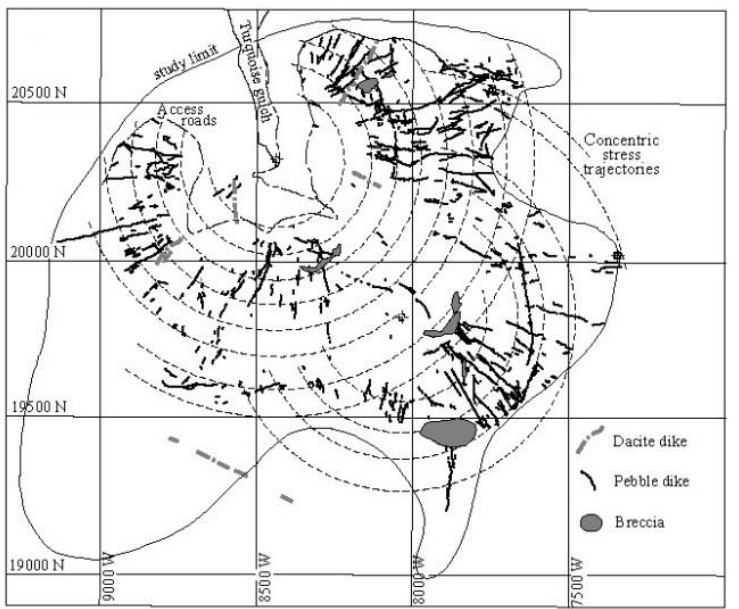

(a)

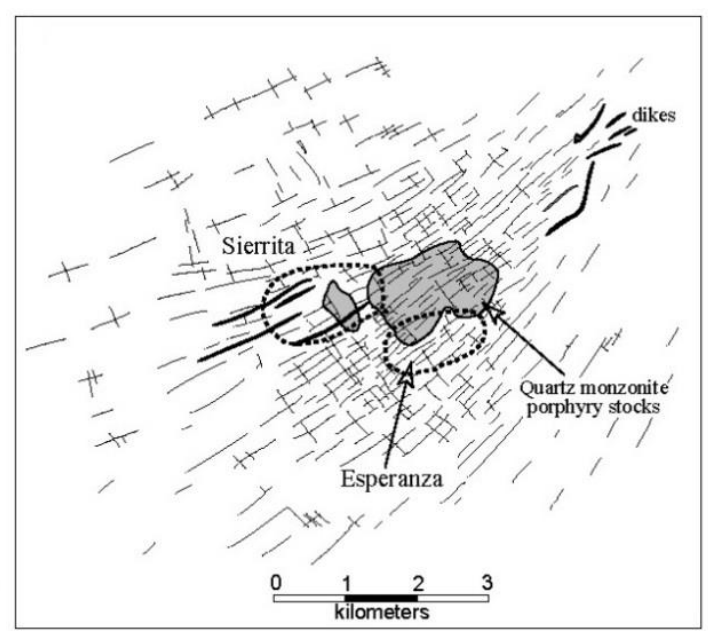

(b)

Figure 19 Jointing patterns associated with intrusion process; (a) radial structures indicative of two domical stocks at depth (dashed lines are interpreted concentric stress trajectories); and, (b) joint pattern is suggestive of a linear structural control (Tosdal \& Richards 2001) 
In summary, intrusion related structural patterns are dependent on the following factors (Corbett and Leach 1997), Figure 20:

- Stress regime into which the intrusion has been emplaced as controlled by the regional structure; for example, orthogonal or oblique convergence.

- Nature of the host rock, particularly if there is any pre-existing rock fabric or structural grain that may induce anisotropy such as may be generated by arc-parallel structures.

- Level of the porphyry system that has been exposed by erosion, which is part of the geological history of the deposit as already discussed.

HIGH LEVEL
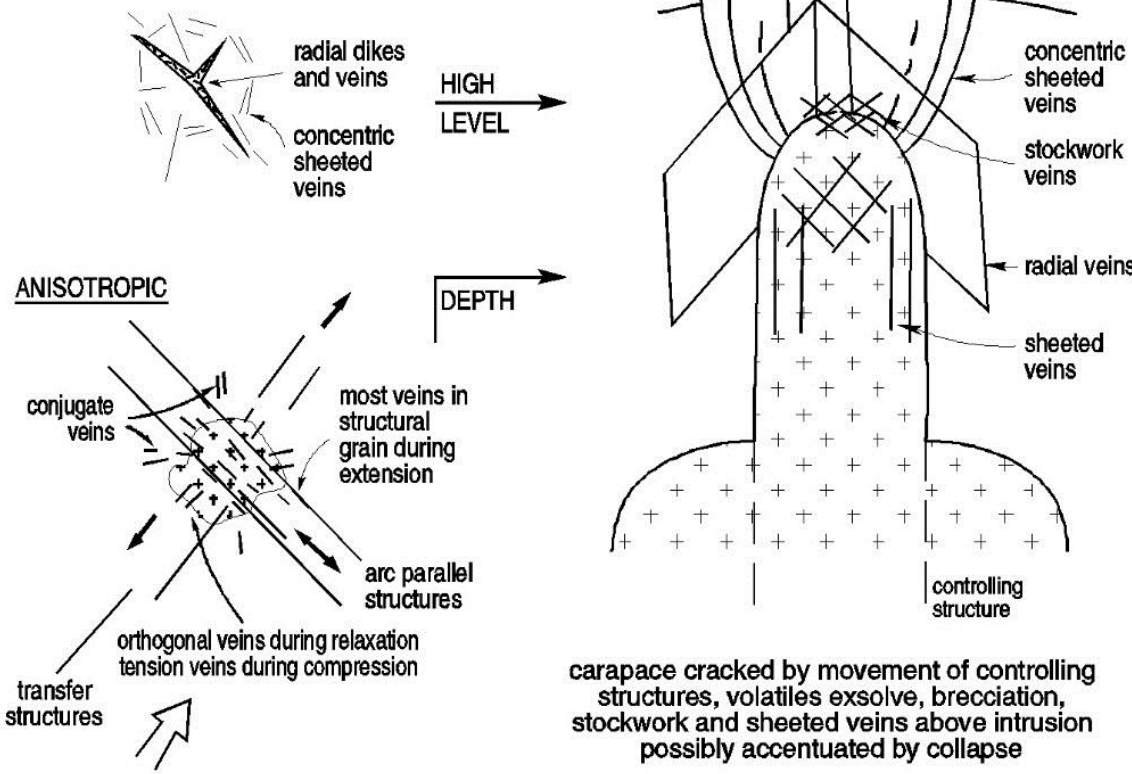

carapace cracked by movement of controlling structures, volatiles exsolve, brecciation, stockwork and sheeted veins above intrusion possibly accentuated by collapse

\section{ISOTROPIC}
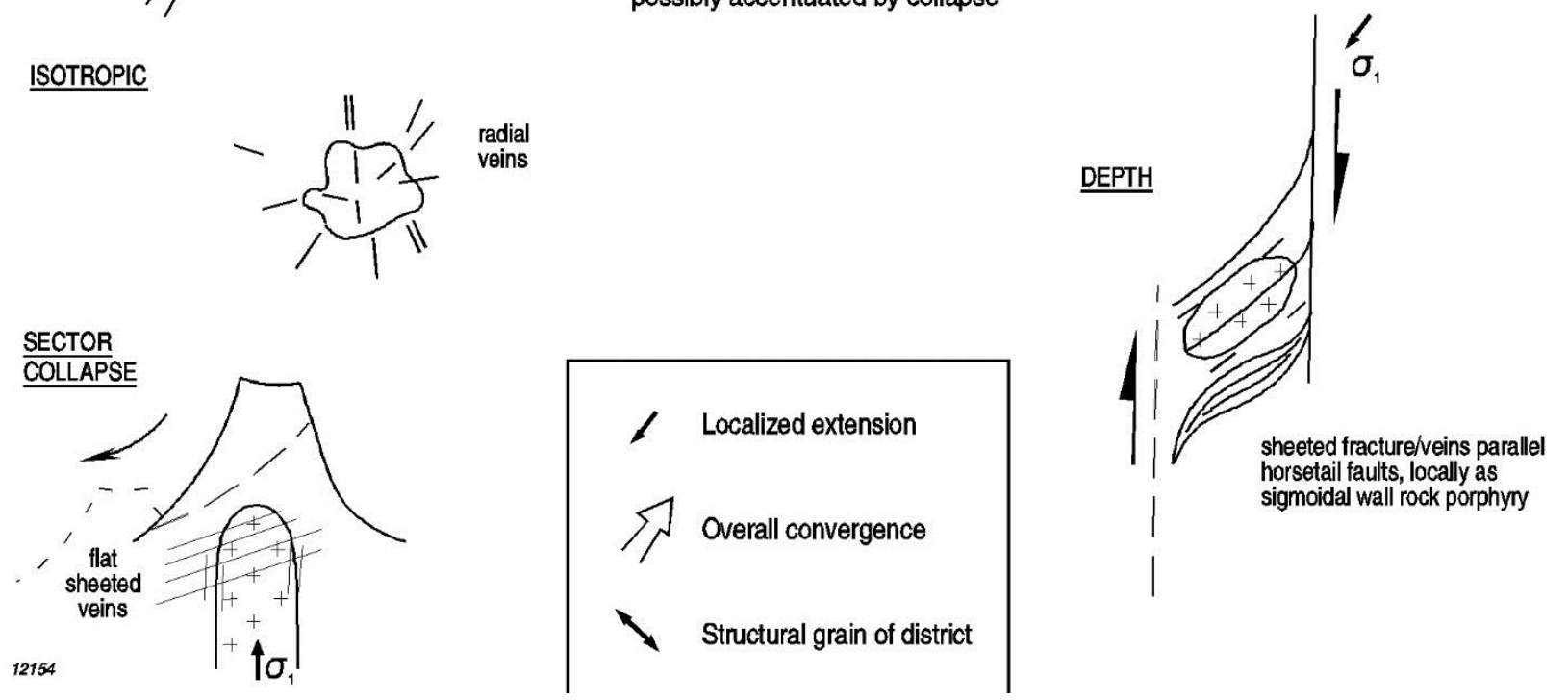

Figure 20 Summary of intrusion related structures showing variation with orthogonal versus oblique convergence stress regimes and depth level of the porphyry system (Corbett and Leach 1997)

High level settings are more influenced by the concentric and radial defect patterns generated at the top of the intrusion and in the overlying host rocks with the concentric structures forming concave upward shapes (Figure 20). Under oblique convergence the concentric and radial pattern can be enhanced along the 
tensional orientation. At deeper levels the regional stress field and local rock fabric have a greater influence and anisotropy can take over as an important structural control resulting in a greater degree of alignment in structural patterns at depth. In more isotropic conditions there is a downward progression from concentric to radial defect patterns (Corbett and Leach 1997). Large scale sector collapse of the associated volcanic artefact can allow low angle defects to develop and generate sub-horizontal breccia at the intrusion contact (Sillitoe 1994).

As with all models of complex geological environments there are always exceptions to these rules and analysis of the structural patterns associated with the intrusion process will require some modification to take account of local conditions. Post-formation of the concentric-radial structures, the stock and the host rocks often undergo further deformation associated with either ongoing hydrothermal activity or more regionally controlled tectonics. The new tectonic stress fields can overprint a new set of structures further complicating the structural patterns. This can make structural interpretation a challenging task often requiring specialist input.

\subsubsection{Summary - key questions}

The aim of the deposit-scale engineering geological model is to investigate and describe elements of the geology that will impact on the rock mass, structural and hydrogeology conditions. To assist unravelling the dynamic geological environment of a porphyry copper deposit, the following key questions should be addressed:

- Is the deposit vein or breccia dominated or is it something in between? What is the distribution of brecciation relative to the basic architecture of the deposit (stocks, host rocks, major structures) and how can this deposit-scale understanding be used to plan how the breccias should be investigated and described?

- What is the deposit specific alteration model and what alteration types can be expected in final limit areas? How does the alteration zonation fit with the distribution of the main rock types (intrusives, volcanics, host rocks)? For example, is there a phyllic zone surrounding the potassic core? Is there a significant lithocap with argillic style alteration?

- Is there a significant zone of supergene alteration and associated oxidation due to weathering? What are the apparent controls on depth and shape of the oxidised zone?

- What is the stress regime in the deposit area, orthogonal or oblique convergence? Are there any regional geological structures that control placement of the deposit such as side stepping strike-slip faults? Are there any deposit-scale faults and shears associated with the regional controls such as pull-apart basin faults and secondary Riedel shears?

- Is there any district to deposit scale extension faulting in the roof rocks from growth of the magma chamber at depth? What level of the porphyry system is exposed, high or deeper level? Any development of concentric and radial joint patterns in the stocks and adjacent host rocks related to the intrusion process? Any fabric or structural grain in the host rocks acting as an anisotropic control on preferred structural alignments?

- Does the structural history of the deposit indicate any tectonic phases post-mineralisation that may overprint the regional and intrusion controlled structures?

Answers to these questions will go a long way to building the geotechnical model, with a focus on the important geological factors controlling slope stability and design. 


\section{Geological controls on rock mass and structure conditions}

Typical industry approaches to geotechnical modelling for porphyry deposits is to undertake a relatively generic rock mass modelling exercise with little attention to the deposit specific geological controls on rock mass conditions. Further, little attention is often paid to the deposit scale structure, which under most conditions is a dominant control on slope stability, as discussed in Section 4. Incorporation of key geological elements into the rock mass and structural components of the geotechnical model is discussed in this section.

\subsection{Description and modelling of porphyry-style breccia}

Porphyry systems are characterised by multiple or recurrent phases of hydrothermal activity leading to repeated fracturing and brecciation and increased complexity. Consequently, there is a wide variety of overlapping breccia characteristics, which reflects a continuum between breccia types.

This section describes systems to record and capture geological observations of the key characteristics controlling engineering behaviour of porphyry-style breccia. A simple engineering geological classification of porphyry-style breccia is proposed with discussion on the difficulties of differentiating between breccia types and the implications of getting the interpretation wrong.

\subsubsection{Engineering geological description}

Describing breccia requires detailed observations on textures, geometries and lithologies. Standard geotechnical logging systems are generally inadequate to capture the essential elements of a porphyry-style breccia required to understand the geological features likely to control engineering behaviour in a slope. As such a specialised logging system has been devised based on experience across a number of porphyry copper deposits. This is a project specific system, which is modified to meet the particular conditions of each deposit. Essentially it incorporates the typical systems for recording observations on the routine rock mass parameters but also includes specific description systems for brecciation and fracturing (Cammack 2016).

The logging system is based on descriptive terms focusing on the geological features of the breccia. The objective of this approach is to allow differing breccia textures and fabrics to be recorded, which can then be used to build a genetic classification based on mode of formation, recognising that breccia is often the product of multiple, overprinting processes. For example, a tectonic breccia may have subsequently been exposed to hydrothermal brecciation by magmatic fluids focused by the fault zone.

The system describes the coherent and brecciated components of the rock separately. For coherent rock, standard geotechnical logging descriptions are used for:

- Rock type (lithology).

- Alteration.

- Grain characteristics.

- Internal structure/texture/fabric.

- Secondary/tertiary components (if any).

For brecciated rock the descriptors used are summarised in Table 1 (Cammack 2016). Separate estimates of strength are recorded for the clasts and matrix. 
Table 1 Breccia description system for geotechnical logging of core

\begin{tabular}{ccc}
\hline Component & Parameter & Comments \\
\hline Clasts & Mode & \% of rock content \\
& Lithology & Rock/alteration type forming clasts \\
& Monomict/polymict & One or more types forming the clasts \\
Size & Equivalent gravel size \\
Shape & Roundness or angularity of clasts \\
Strength & Mode & Intact strength of clasts \\
& Grain size & \% of rock content \\
& Strength & Mud (silt/clay) or sand \\
& Cement type & Intact strength; may be soil strength \\
& Clast/matrix supported & Cement mineralogy \\
& Clast arrangement & Clasts touching? \\
& & Crackle/mosaic/rotated/chaotic breccia \\
& (see Table 2$)$ \\
\hline
\end{tabular}

The adopted breccia fabric clast arrangement descriptions are illustrated in Table 2. An important component is the mode of clasts and matrix and whether the breccia is clast or matrix supported, as these factors can have a major influence on the engineering properties of the breccia rock mass.

Table 2 Fabric arrangement for highly fractured and fragmented zones

\begin{tabular}{|c|c|c|c|c|}
\hline Symbol & Fabric type & $\begin{array}{l}\text { Approx. } \% \text { of } \\
\text { clasts }\end{array}$ & Graphic & Description \\
\hline Ck & $\begin{array}{l}\text { Crackle } \\
\text { breccia }\end{array}$ & $75-98 \%$ & & $\begin{array}{l}\text { Fractured with no or little separation } \\
\text { (clast supported) }\end{array}$ \\
\hline$M z$ & $\begin{array}{l}\text { Mosaic } \\
\text { breccia }\end{array}$ & $50-75 \%$ & & $\begin{array}{l}\text { Rock fragments/clasts in situ with } \\
\text { separation } \\
\text { (clast or matrix supported) }\end{array}$ \\
\hline Rt & $\begin{array}{l}\text { Rotated } \\
\text { breccia }\end{array}$ & $40-60 \%$ & & $\begin{array}{l}\text { Rock fragments/clasts rotated } \\
\text { (matrix supported) }\end{array}$ \\
\hline $\mathrm{Ch}$ & $\begin{array}{l}\text { Chaotic } \\
\text { breccia }\end{array}$ & $30-50 \%$ & & $\begin{array}{l}\text { Rock fragments/clasts disorientated } \\
\text { (matrix supported) }\end{array}$ \\
\hline
\end{tabular}


Coupled with the breccia descriptors, the degree of fracturing in specific zones is recorded using the terms listed in Table 3.

Table 3 Degree of fracturing terms

\begin{tabular}{ccc}
\hline Symbol & Term & Description \\
\hline $\mathrm{SF}^{1}$ & Slightly fractured & $>30 \mathrm{~cm}$ spacing between defects \\
$\mathrm{FR}^{1}$ & Fractured & $10-30 \mathrm{~cm}$ spacing between defects \\
$\mathrm{HF}^{2}$ & Highly fractured & $3-10 \mathrm{~cm}$ rock fragment size \\
$\mathrm{FG}^{2}$ & Fragmented & $<3 \mathrm{~cm}$ rock fragment size \\
\hline
\end{tabular}

'Include description of typical defect type within zone. ${ }^{2}$ Insert suffix ' $c$ ' when there is a clay matrix (e.g. FGc) and describe the fabric arrangement of the breccia (Table 2)

Other standard geotechnical rock and structural components, which should be recorded as part of the logging include:

- Colour.

- Weathering (see discussion in Section 3.2).

- Rock quality designation (RQD).

- Fracture spacing.

- Core recovery.

- Defect description (type, orientation, shape, surface roughness, infill type and thickness).

This logging information can be presented as graphical geotechnical logs to display the varying conditions encountered within each borehole with an emphasis on visual presentation of the matrix and fabric characteristic within brecciated zones. The graphical borehole logs, used in conjunction with core photographs and downhole borehole imaging, combine as a powerful tool to define zones of similar rock mass character downhole.

This logging system provides more weighting towards the lower end of the rock mass quality spectrum. It enables better separation of, for example, poor quality rock from very poor quality rock, which often characterises porphyry-style deposits. It allows subtle changes in rock mass character to be differentiated, which can be important for successful slope design.

Interpretation of breccia origin can be difficult when the main data source is cored boreholes. The complete textural relationships required to make a successful identification may not be captured at the core scale. Further, poor drilling practices often result in the weakly cemented matrix of some breccias being washed away. This leaves the clast content in the splits giving the false appearance of a fractured to fragmented rock.

Measurement of RQD is also problematic in brecciated and fractured porphyry rocks where disturbance of the core during drilling and handling can artificially fracture the rock, particularly in crackle and mosaic breccia zones or zones of incipient or weakly rehealed fractures. It is important that RQD, fracture frequency and other structural and textural observations of the core are made in the splits at the rig before boxing. The core should also be routinely photographed in the splits before any handling, and the RQD logs should be checked against borehole imaging surveys to help recalibrate measurements.

These factors go towards assessment of the data quality and representativeness, which are paramount questions that should always be asked when assessing engineering geological data for geotechnical modelling (Sullivan 2010). 


\subsubsection{Simple engineering geological classification}

For engineering geological classification of breccia the focus should be on the fundamental differentiation between hydrothermal, volcanic and tectonic breccia and not necessarily divide breccia rocks into all the hydrothermal sub-types. The premise of this approach is to ensure the main breccia origin is captured to allow for adequate engineering description of the important characteristics and appropriate modelling of different breccia zones.

Usually identification of volcanic breccia is relatively straightforward by location in the geo-model; that is, not in the intrusives or non-volcanic country rock. However, differentiation between hydrothermal and tectonic breccias can be more problematic. This separation is important as modelling discrete fault zones in 3D using borehole data, hopefully in concert with surface lineament mapping, is challenging enough without the interpretation being made more difficult with spurious identification of downhole tectonic breccia zones.

Differentiating between these fundamental breccia types requires detailed observations on textures, geometries and lithologies. Some guidelines include:

- Hydrothermal breccia can produce a range of textures, however, most form a jigsaw-fit to the clasts with variable matrix development (crackle to mosaic breccia) resulting in a 'shattered' appearance. Examples of this are shown in Figure 21. In the more mobile breccia zones there can be a gradation in breccia fabric from rotational to mosaic to crackle breccia with increasing distance from the magmatic source. The rotation is due to substantial clast transport where there is considerable fluid movement while the mosaic breccia signifies little or no transportation. On the other hand, in some areas the breccia contact with the country rock is abrupt. Early stage brecciation can often be rehealed while the matrix in late stage breccia may be less cemented.

- Volcanic (including autoclastic) breccia normally does not produce jigsaw-fit clast textures (crackle and mosaic breccia) due to the transportation of clasts, which causes rotation.

- Tectonic breccia often shows a shear fabric in the matrix and clasts can be stretched or strained.
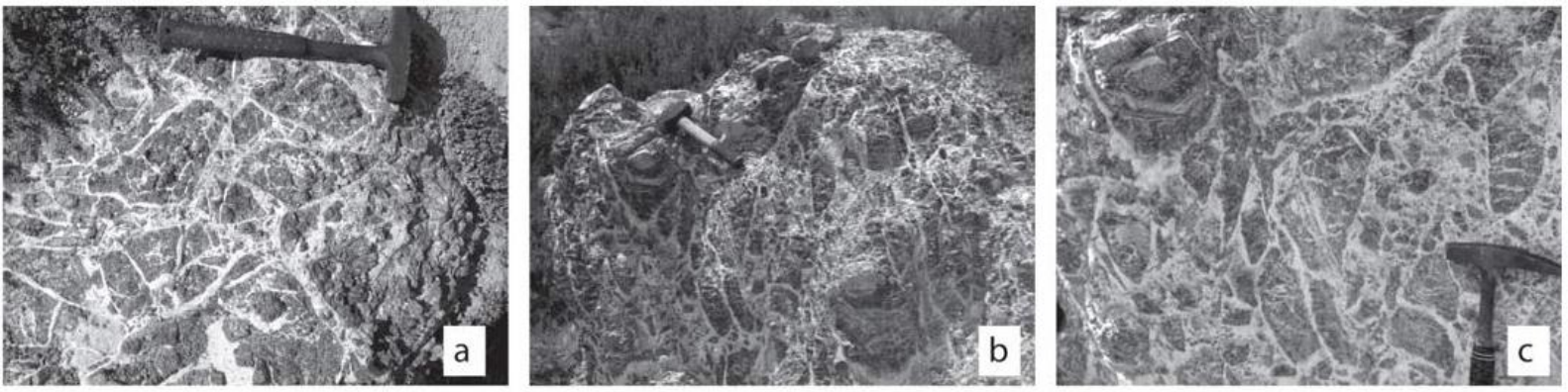

Figure 21 Hydrothermal breccia showing a jigsaw-fit texture with polygonal shaped clasts and variable matrix development resulting in a crackle to mosaic fabric; (a) shows an isotropic clast arrangement whereas (b) and (c) show a sub-vertical clast arrangement likely aligned along the travel direction of the hydrothermal fluids (Cas et al. 2011)

Confident identification of hydrothermal versus tectonic breccia is made difficult in large faults with wide crush zones. Significant generation of matrix can occur in these zones without any development of a shear fabric adjacent to the main gauge zone where most of the shearing is concentrated. If the gauge zone is not intersected by drilling to confirm the identification by association, crush breccia can often resemble matrix supported hydrothermal breccia resulting in misidentification.

\subsection{Alteration and weathering effects}

The overall impact of alteration and weathering processes is change in rock mass quality compared with the original rock. Both processes produce changes of the mineralogical composition of a rock, affecting colour, texture and composition, which typically manifests as degradation in rock mass quality due to a 
reduction of the mechanical properties of the rock. The main controls on weathering are the pre-weathering rock composition, post-mineralisation hydrogeology, cycles of uplift and climate. In the high rainfall environment prevalent in Southeast Asia, weathering can be an important feature of the rock mass model causing oxidation to significant depths.

In some circumstances, alteration and weathering processes can result in an improvement in overall rock mass quality. New minerals can be deposited in intergranular voids during weathering or alteration, which act as cements and cause the intact strength to increase. This phenomenon can be difficult to record using some commonly adopted weathering classification schemes, which judge an increase in degree of weathering as an increase in the proportion of rock material that has decomposed and/or disintegrated to a soil (e.g. ISRM 1978). As such, weathering is estimated in these schemes by a progressive loss of intact strength, that is, they use strength as a proxy for weathering. There are other weathering classifications, such as the McMahon Douglas Burgess system (McMahon et al. 1975), which do not assume a progressive loss of strength must occur as an effect of increased weathering (or alteration). These systems are preferred for description of porphyry rocks.

A relative ranking of rock mass quality for the main alteration categories is presented in Table 4. This ranking is highly generalised but reflects the overall change in rock mass character due to alteration impacts. This ranking approximates the vertical zonation of alteration, as presented in Figure 12, whereby shallower alteration zones overprint and partly reconstitute deeper types. This telescoping generally results in deterioration in rock mass quality with increasing over-printing.

Table 4 Generalised ranking of rock mass quality for main alteration categories

\begin{tabular}{ccc}
\hline Alteration system & Alteration type & Relative rock mass quality \\
\hline Epithermal & Argillic & Worst \\
& Advanced argillic & Phyllic \\
Porphyry & Potassic & Best \\
& Propylitic & \\
\hline
\end{tabular}

Progressive acid leaching changes potassic to phyllic alteration, which can be viewed as a type of 'chemical brecciation' or corrosive wear involving selective or pervasive dissolution. The net result is typically a lowering in intact strength and increase in degree of fracturing.

Late in the phyllic alteration phase there can be an extensive stockworking of quartz-anhydrite-pyrite(chalcopyrite), which results in voluminous precipitation of anhydrite. This produces a very good quality rock in contrast with the typical fractured nature of porphyry rocks. However, subsequent dissolution of anhydrite generates gypsum, which has a relatively higher molar volume compared with anhydrite. This transformation causes the rock to splinter or break-up resulting in a highly fractured to fragmented rock mass. The gypsum-anhydrite transition can occur in just several metres thickness or less and marks an important engineering geological boundary in the rock mass model. This condition is important in many Southeast Asia porphyry deposits including at Grasberg where the dissolved zone is called 'poker chip'.

In some deposits there can be a marked disintegration of core within weeks to months after drilling. This occurs in relatively high intact strength diorite porphyry rocks characterised by incipient partially healed fractures. Petrological work suggests the mechanism of breakdown involves a number of microstructural and compositional features that combine to produce a complex model of mechanical and chemical deterioration. In summary, the mechanism involves:

- Mechanical factors - physical degradation due to intense microfracturing, microbrecciation and grain boundary weakening; aided by expansion of the core due to stress relief. 
- Chemical factors - chemical degradation of sulphides and clay minerals exposed by the mechanical breakdown.

This has implications to material handling, trafficability of ramps and haul roads and deterioration of rock faces on benches, which can increase the potential for acid generation reporting to surface water flows.

Overall, in geotechnical studies for pit slope design, little attention is paid to understanding alteration and weathering processes with the focus just on characterising the end result. However, some knowledge of the processes can be important for understanding and interpreting the geological conditions of the rocks forming the pit wall.

\subsection{Structural modelling}

The regional and deposit-scale structural features described in Section 2, while useful, are very much idealised. The caveat when using these types of models is that not all of the features explained in these fault association reproductions are normally seen at any one deposit. Actual patterns never quite fit the theory principally due to overprinting of other deformation style from later events. Generational analysis requires a skilled and experienced hand to correctly unravel the detailed structural history. Sometimes a simplified structural model suits the purpose for engineering geological purposes, occasionally a structural geologist is required to decipher the model in sufficient detail to enable the capture of key features that are likely to control slope stability and design.

Some tools to help with structural modelling include:

- Understanding the hierarchy of structures.

- Confidence interpretation of the major structures.

\subsubsection{Hierarchy of structures}

Evaluation of a hierarchy or order of structures assists with understanding which defects will control stability at different slope scales. This may be as simple as dividing the defect population into major and minor structures whereby major structures control at the inter-ramp to overall slope scales while minor structures are likely to be only important at the individual bench scale. Innately, faults and shears are major structures and joints are dominantly minor defects. Joints in a porphyry deposit are typically non-persistent and relatively short. Therefore, they largely do not extend beyond a single bench. However, this should be evaluated for each specific deposit.

In a structurally complex deposit a more sophisticated hierarchy scheme may be required to capture all the elements important for structural modelling. During scoping to feasibility studies the available data is mostly from boreholes. As such the following scheme assists with interpretation of major structures from borehole logs, core photographs and downhole images:

- Primary order structures - clay gouge or pug seam surrounded by a wider clay breccia zone with a higher proportion of matrix supported, chaotic to rotated breccia fabric; this zone may grade into a fragmented to highly fractured zone changing from matrix to clast supported, mosaic to crackle breccia depending on the width and nature of the 'damage' zone.

- Secondary order structures - lesser development of a clay breccia zone without a significant gouge or pug zone inside fragmented to highly fractured rock.

- Tertiary order structures - fragmented to highly fractured rock in the immediate footwall and hanging wall of the fault plane without development of gouge or clay breccia materials.

The focus is on evaluating the nature of fault infill materials and conditions of the fault wall rocks in the 'damage' zone. The assumption is the order rankings are considered an indication of the lateral continuity of structures. 


\subsubsection{Fault classification and confidence rating}

Interpretation of the structural model is often based on a number of data sources, principally evaluation of borehole intersections supported by an air photo and/or a Lidar lineament study and sometimes with the availability of surface exposures to map. The system presented in Table 5 enables all these data sources to be brought together to classify each structure.

Table 5 Fault classification

\begin{tabular}{ccc}
\hline Airphoto/Lidar lineament & Drillhole intersection & Surface exposure \\
\hline $\mathrm{Y}$ - with & 1 -with & $\mathrm{y}$ - with \\
$\mathrm{N}$ - none & 0 -without & $\mathrm{n}$ - none \\
\hline
\end{tabular}

The fault classification is used to rate each structure for the level of confidence that the structure has been accurately predicted (Table 6).

Table 6 Fault confidence rating

\begin{tabular}{ccc} 
Rating no. & Classification & Rating descriptor \\
\hline 1 & Y1y & High \\
2 & YOy, Y1n, N1y & Medium \\
3 & YOn, N1n, N0y & Low \\
\hline
\end{tabular}

The confidence rating and hierarchy evaluation contributes directly to knowledge of which structures can be relied on for stability analysis and at what slope scale the structure may impact on stability conditions.

\section{$4 \quad$ Model examples and pit slope instability}

Some examples of different components of the overall engineering geological model are presented to illustrate the nature and style of a developed model formulated for the primary purpose of pit slope design. Part of this design objective is slope depressurisation and pore pressure modelling and, as such, the models are sufficiently developed to also assist with characterising hydrogeological conditions for mine dewatering studies. Other design objectives for which the engineering geological models can be extended include material handling, in-pit trafficability and waste dump design.

Separate model examples are provided for rock mass and structure and finish with some key findings from research on pit wall failures from a deposit in Indonesia.

\subsection{Rock mass model}

This example comes from a feasibility study for a deposit in the Philippines, which is centred on a transfer fault system that acts as a suture associated with the Eurasian and Philippine Sea plate boundary. The deposit sits on the flank of an uplifted and eroded stratovolcanic complex. The deposit occurs in association with a diorite stock hosted by a series of thick, massive andesitic lava flows with some intercalated flow breccias but no significant interbedded pyroclastic horizons.

Several breccia types occur throughout the deposit that impacts on rock mass conditions. These comprise:

- Early and locally developed autoclastic flow breccias (solidified crust and/or basal friction breccias) and intrusion carapace breccias.

- Spatially restricted intermediate stage diatreme breccias.

- Ubiquitous syn-high sulphidation hydrothermal breccias.

- Fault breccias. 
Alteration is a vertically zoned argillic, advanced argillic and intermediate argillic hydrothermal system that is transitional outwards to a regional propylitic alteration type (Table 7). Anhydrite veining occurs below a narrow (less than one metre thick) undulating to sub-horizontal transition in the intermediate argillic zone. Above this transition the advanced argillic sequence is highly fractured, whereas below the line the rock mass is of better quality.

\section{Table 7 Alteration zonation}

\begin{tabular}{|c|c|c|c|c|c|c|}
\hline \multicolumn{2}{|c|}{ Alteration } & \multirow{2}{*}{ Distribution } & \multirow{2}{*}{ Description } & \multirow{2}{*}{\multicolumn{3}{|c|}{ Mineralisation }} \\
\hline Type & Sub-type & & & & & \\
\hline \multicolumn{2}{|c|}{ Argillic (ARG) } & Uppermost alteration & $\begin{array}{l}\text { Illite-smectite- } \\
\text { chlorite }\end{array}$ & \multicolumn{2}{|c|}{ Minor mineralisation } & \multirow{3}{*}{ 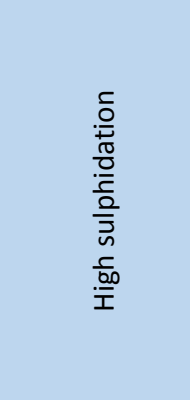 } \\
\hline \multirow{3}{*}{$\begin{array}{l}\text { Advanced } \\
\text { argillic }\end{array}$} & Silicic & $\begin{array}{l}\text { Upper sub-type of the } \\
\text { advanced argillic } \\
\text { alteration }\end{array}$ & Silica 90\% & \multirow{3}{*}{$\begin{array}{l}\text { Host to the } \\
\text { majority of } \\
\text { copper in the } \\
\text { deposit }\end{array}$} & & \\
\hline & Silica-clay & $\begin{array}{l}\text { Underneath and sharp } \\
\text { contact with silicic } \\
\text { horizon or enclosing } \\
\text { lenses of massive silica }\end{array}$ & Silica 50-90\% & & HS1 & \\
\hline & Clay-silica & $\begin{array}{c}\text { Transitional downwards } \\
\text { to a clay rich } \\
\text { assemblage }\end{array}$ & Clay 50-90\% & & HS2 & \multirow{4}{*}{$\begin{array}{l}\frac{2}{2} \\
\frac{1}{2} \\
\frac{2}{0} \\
0\end{array}$} \\
\hline \multirow{2}{*}{$\begin{array}{l}\text { Intermediate } \\
\text { argillic (IAR) }\end{array}$} & & $\begin{array}{l}\text { Gradational with } \\
\text { overlying clay-silica } \\
\text { subzone }\end{array}$ & $\begin{array}{c}\text { Sericite-clay } \\
\text { (illite)-chlorite, } \\
\text { abundant silica and } \\
\text { pyrite }\end{array}$ & \multirow{2}{*}{$\begin{array}{l}\text { Outer shell of } \\
\text { porphyry system }\end{array}$} & Gypsum- & \\
\hline & Anhydrite & $\begin{array}{l}\text { Occurs below the } \\
\text { gypsum-anhydrite } \\
\text { transition at depth }\end{array}$ & Anhydrite veins & & \multirow[t]{2}{*}{$\begin{array}{c}\text { anhydrite } \\
\text { transition } \\
\text { (GAS) }\end{array}$} & \\
\hline Pota & & $\begin{array}{l}\text { Margin of host diorite } \\
\text { intrusives at depth }\end{array}$ & $\begin{array}{l}\text { Relict assemblage of } \\
\text { biotite-magnetite- } \\
\text { anhydrite }\end{array}$ & $\begin{array}{l}\text { Volumetrically } \\
\text { insignificant }\end{array}$ & & \\
\hline \multicolumn{2}{|c|}{ Propylitic (PRO) } & $\begin{array}{l}\text { Generally restricted to } \\
\text { higher stratigraphic } \\
\text { levels at the periphery } \\
\text { of the deposit }\end{array}$ & $\begin{array}{l}\text { Chlorite-epidote } \pm \\
\text { clay alteration }\end{array}$ & \multicolumn{2}{|c|}{$\begin{array}{l}\text { Anomalous in copper and } \\
\text { gold }\end{array}$} & $\begin{array}{l}\text { Regional } \\
\text { alteration } \\
\text { outside } \\
\text { mineralisation }\end{array}$ \\
\hline
\end{tabular}

Rock mass modelling investigated a possible connection between alteration types and rock mass quality. Borehole core and logging data together with laboratory test results were filtered by alteration type in an attempt to disclose patterns or unique characteristics for the different alteration types. Although some relationships were discovered, it appeared that in most areas similar rock mass properties extended across different alteration types and were substantially controlled by the degree of fracturing and brecciation.

The rock mass units interpreted for this deposit are listed in Table 8 with example core photographs from the fractured and highly fractured rock and hydrothermal breccia units shown in Figure 22. 
Table 8 Rock mass units

\begin{tabular}{|c|c|c|c|}
\hline \multirow{2}{*}{$\begin{array}{l}\text { Rock mass } \\
\text { category }\end{array}$} & \multirow{2}{*}{ Rock mass description } & \multicolumn{2}{|c|}{ Correlation with geological model } \\
\hline & & Alteration/rock type & Faulting \\
\hline WR & 'Weathered rock' & - $\quad$ ARG/EW-HW rock & \\
\hline FR & $\begin{array}{l}\text { 'Fractured rock' with high to moderate RQD, no } \\
\text { clay and isolated shears }\end{array}$ & $\begin{array}{ll}\text { - } & \text { Below GAS } \\
\text { - } & \text { Late stage andesite }\end{array}$ & $\begin{array}{l}\text { Outside major } \\
\text { fault zones }\end{array}$ \\
\hline $\mathrm{HF}$ & $\begin{array}{l}\text { 'Highly fractured rock' with low RQD, occasional } \\
\text { shears and breccia zones }\end{array}$ & $\begin{array}{ll}\text { - } & \text { PRO } \\
\text { - } & \text { Better quality IAR }\end{array}$ & \\
\hline FG & $\begin{array}{c}\text { 'Fragmented rock' with very low to zero RQD; } \\
\text { some clay matrix development (clast supported) } \\
\text { with some shears }\end{array}$ & $\begin{array}{ll}\text { - } & \text { HS1, HS2 } \\
\text { - } & \text { Poorer quality IAR }\end{array}$ & $\begin{array}{l}\text { Generally outside } \\
\text { major fault zones }\end{array}$ \\
\hline $\mathrm{HBx} / \mathrm{FBx}$ & $\begin{array}{l}\text { 'Clay breccia' (matrix supported) with numerous } \\
\text { sheared zones and no drill water return }\end{array}$ & $\begin{array}{ll}\text { - } & \text { ARG/EW-HW rock } \\
\text { - } & \text { Intensely hydrothermally } \\
\text { brecciated rock (poorer } \\
\text { zones of HS2) }\end{array}$ & Fault breccia \\
\hline FC & $\begin{array}{c}\text { 'Crushed rock' typically characterised by } \\
\text { very/extremely low strength rock and no drill } \\
\text { water return }\end{array}$ & Independent of rock type & Fault crush seams \\
\hline
\end{tabular}

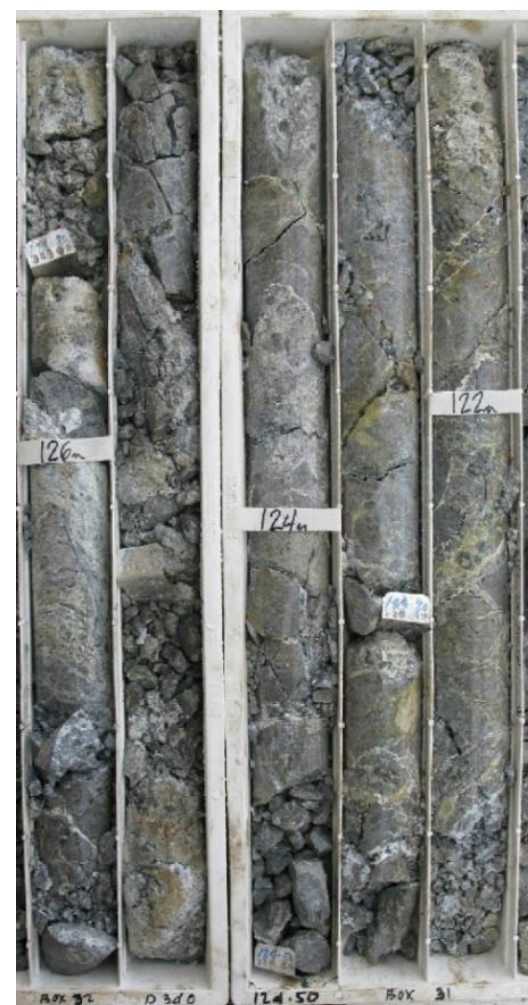

(a)

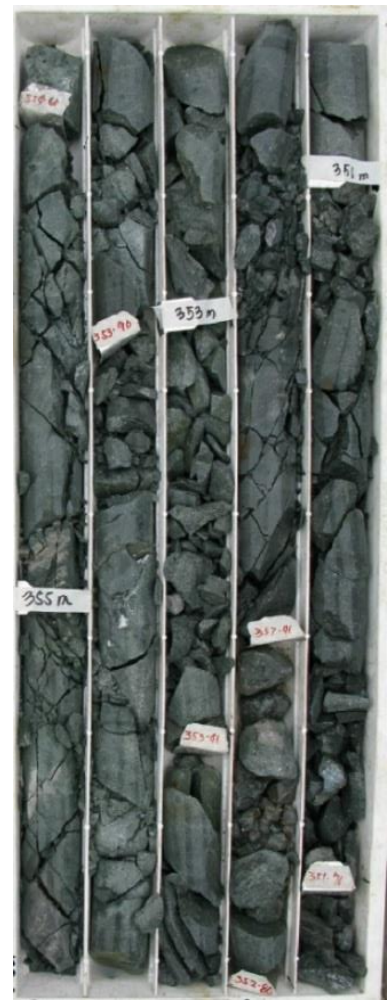

(b)

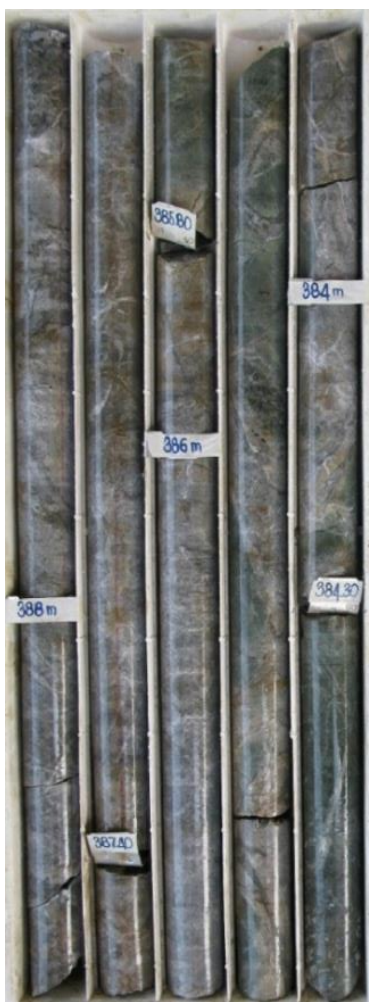

(c)

Figure 22 Core photographs of selected rock mass units illustrating typical conditions:

(a) $\mathrm{HBx}$ - example of hydrothermal breccia dominantly comprising a mosaic fabric with intervals of matrix and clast supported breccia; (b) HF - highly fractured rock with low RQD and some discrete shear zones; and, (c) FR - example of the high quality rock below the gypsum-anhydrite transition

The 'clay breccia' is not a genetically based unit as separating brecciation between hydrothermal and faulting mechanisms was not always possible with the reliance on borehole data only. 
An example of a typical geotechnical cross-section is depicted in Figure 23, which demonstrates how the rock mass units are modelled in preparation for slope stability analysis. The model indicated 'poddy' or 'lensoidal' occurrences of hydrothermal breccia, which appeared to be broadly associated with the major structures intersecting the pit suggestive of the possible structural control on fluid flow. The upper surface of the anhydrite zone was defined, which indicated the level where better quality rock mass conditions would be encountered, and below which structural stability mechanisms would govern slope design.

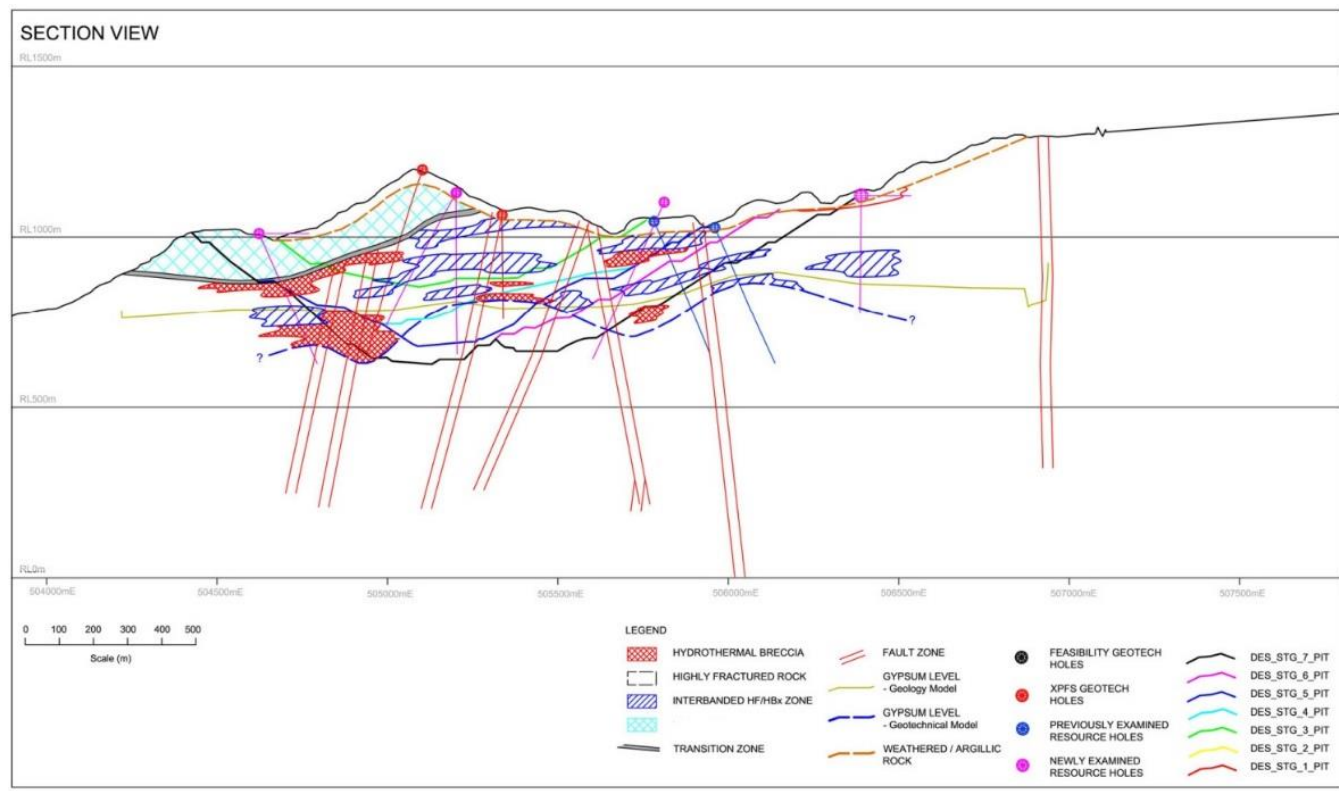

Figure 23 Example of a geotechnical section showing the distribution of rock mass units

Above the gypsum-anhydrite transition the worst rock mass conditions are dominated by relatively continuous bands of hydrothermal breccia $(\mathrm{HBx})$ and combinations of thinly interbanded fractured rock (FR) to highly fractured rock (HF) and HBx units broadly dipping out of the proposed wall. Analysis demonstrated that the worst case scenario critical failure path followed the lower most combination FR/HF and $\mathrm{HBx}$ band with the upper portion of the failure geometry involving mass failure through $\mathrm{FR} / \mathrm{HF}$ rock (Figure 24). However, in a majority of areas the typical critical mechanism involves planar sliding along a non-daylighting rear fault plane and toe breakout through either HBx or HF rock mass.

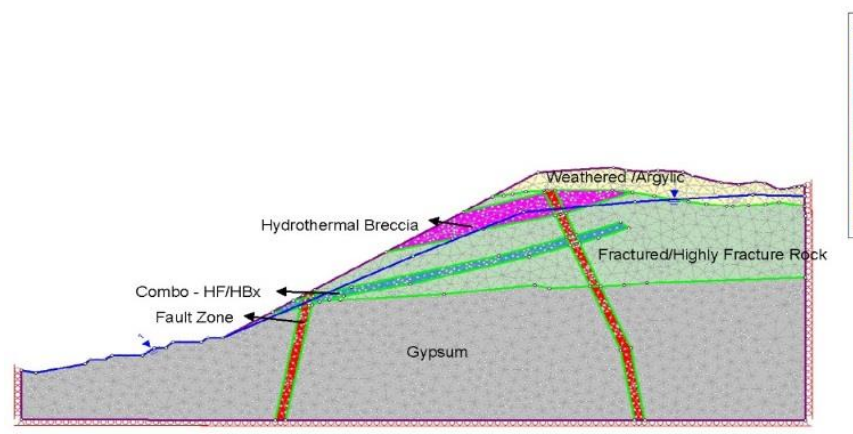

(a)

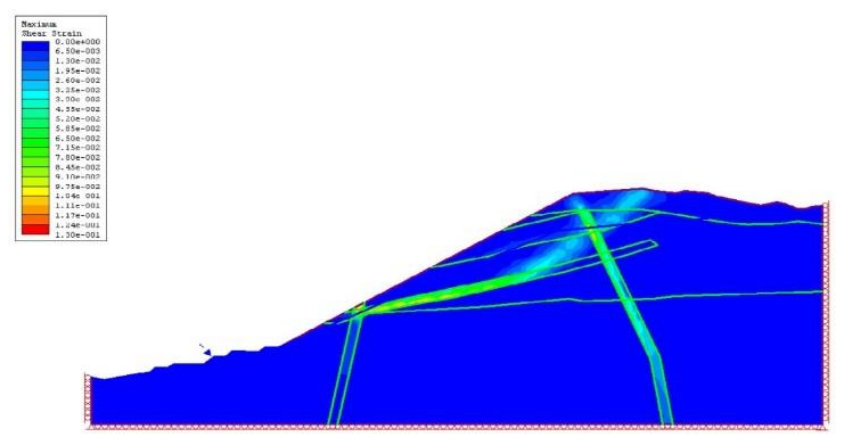

(b)

Figure 24 Example of finite element analysis to investigate the shape of the critical failure surface as controlled by the rock mass model: (a) overall geometry of the model; and, (b) maximum shear strain highlighting the failure mechanism fundamentally controlled by a discrete band of interlayered $\mathrm{HF}$ and $\mathrm{HBx}$

This case example highlights the importance of understanding the brecciation and alteration influences on the rock mass model and how this translates to an improved understanding of geological controls on slope failure mechanisms. 


\subsection{Structural model}

The regional setting of the Grasberg porphyry copper-gold deposit in Indonesia was outlined in Section 2.1.2 as an example of an extensional stepover between strike-slip faults. This regional picture was used to review the pit-scale structural model of the deposit to update structural domains for pit slope design. Previous domains were based on a radial model with an emphasis on assessing the distribution of joint data across the pit, which appear to be dominated by the radial-concentric model (Figure 25(a)). However, this approach did not take full account of the pit-scale faulting and shearing, which was not well defined by a purely radial model.

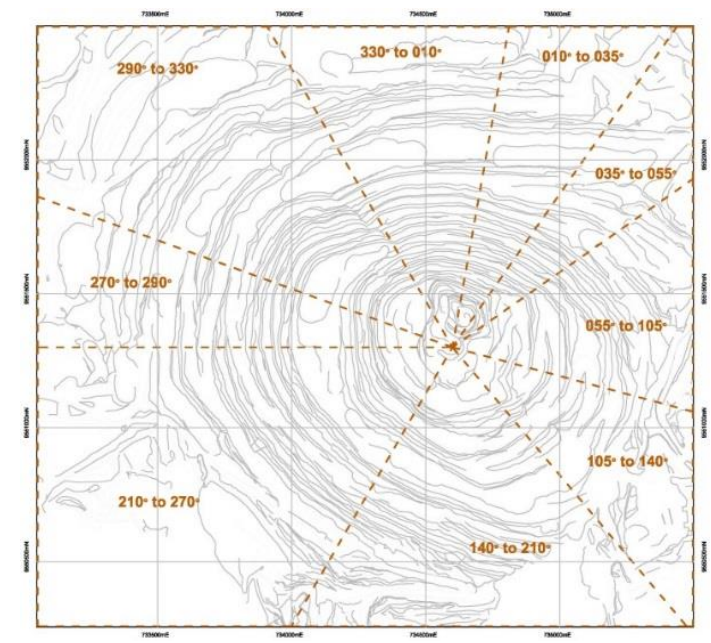

(a)

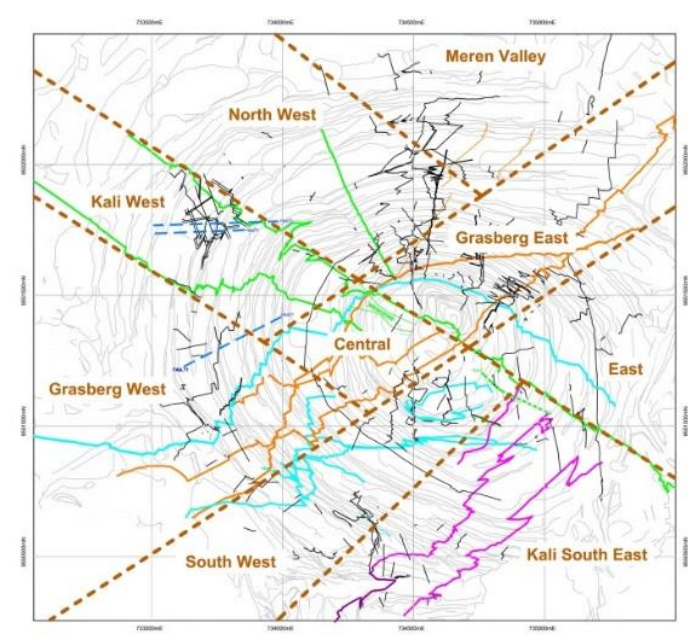

(b)

Figure 25 Alternate structural domain models for the Grasberg open pit; (a) radial model; and, (b) block model with pit scale structures shown

The conceptual understanding used to reassess structural domains is summarised in Figure 26. The approach entailed comparing regional structural controls against existing mapping of the pit exposures, in particular structures associated with a pull-apart basin with an overprint of secondary shears based on the Riedel shear model. The radial and concentric jointing associated with the intrusion process has been superimposed on this fault and shear system.

A) REGIONAL STRUCTURES

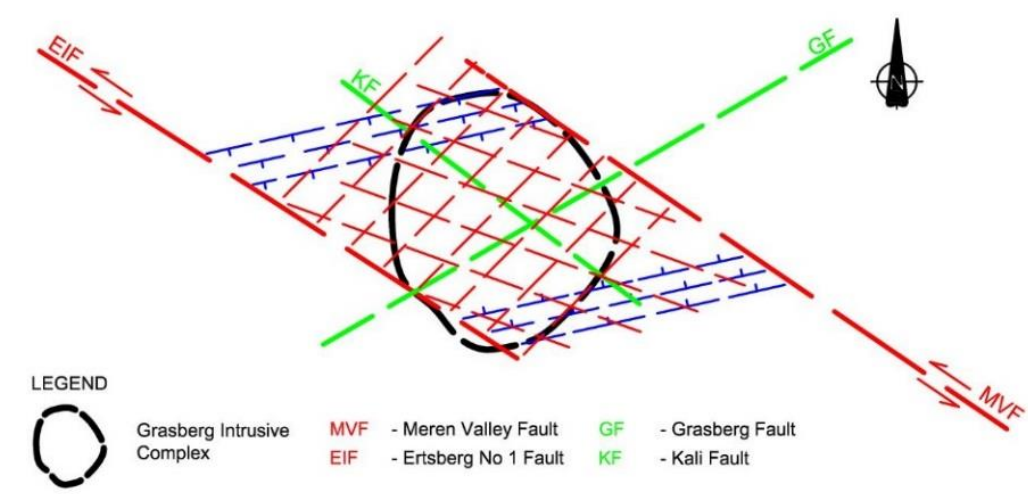

B) INTRUSION STRUCTURES

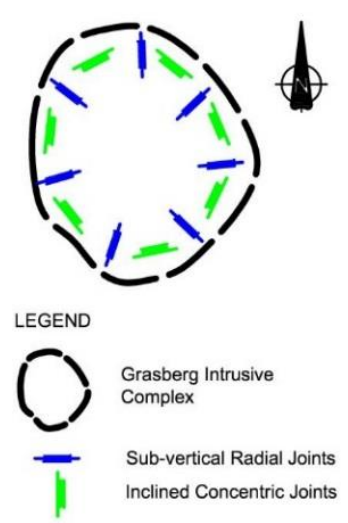

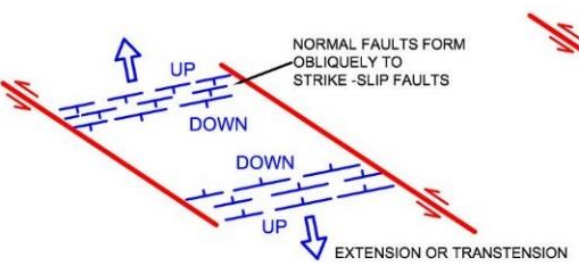

PULL - APART BASIN FEATURES

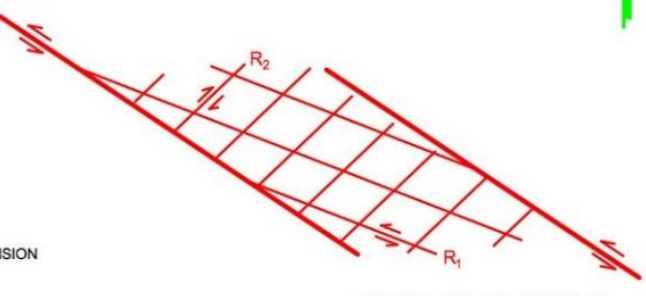

RIEDEL SHEAR SYSTEM

Figure 26 Conceptual structural model of the Grasberg open pit used to assess structural domains 
The updated domains are shown in Figure 25(b). This is a block domain model based on intersecting structural corridors, which delineate zones of preferred structural directions in the intermediate scale faults and shears as controlled by the pit-scale structures. The intention was for this model to be used to update structural slope stability assessments as part of the periodic reviews of slope design.

\subsection{Slope instability mechanisms in porphyry open pits}

Study of pit wall failures for a porphyry copper-gold mine in Indonesia highlights some important features and controls on slope instability mechanisms in porphyry-style deposits. This information helps focus attention on components of the engineering geological model, which are essential to understand for slope design.

The geology of the pit comprises andesite volcanic breccia, volcaniclastic sediments, porphyritic andesite and diorite intrusive stocks, which has been overprinted by an extensive hydrothermal alteration system. Pit-scale faults and shears show a clear relationship with regional structures and show a hierarchical order. Lower order joints form an approximate concentric pattern around the pit. A feature of many faults is they are curved in shape and flatten with depth. A survey of around 120 pit wall failures shows some clear patterns on controlling slope instability mechanisms as summarised in Table 9.

Table 9 Summary of pit wall failure mechanisms

\begin{tabular}{|c|c|c|c|}
\hline Failure type & Mechanism & Percent & e occurrence \\
\hline \multirow[t]{2}{*}{ Planar sliding } & - Daylighting structure & $12 \%$ & \multirow{2}{*}{$20 \%$} \\
\hline & - Composite with rock mass toe breakout & $8 \%$ & \\
\hline \multirow[t]{6}{*}{ Wedge failure } & - Daylighting & $27 \%$ & \multirow{6}{*}{$69 \%$} \\
\hline & $\begin{array}{l}\text { - One-sided wedge along a fault and rock mass failure at } \\
\text { toe and side }\end{array}$ & $16 \%$ & \\
\hline & - Triangular-shaped wedge with rock mass failure at toe & $9 \%$ & \\
\hline & $\begin{array}{l}\text { - Narrow vertical wedge formed by faults with } \\
\text { daylighting of joints at the toe }\end{array}$ & $5 \%$ & \\
\hline & $\begin{array}{l}\text { - Narrow vertical wedge with non-daylighting of } \\
\text { structures at the toe }\end{array}$ & $6 \%$ & \\
\hline & $\begin{array}{l}\text { - Wide wedge with non-daylighting structures and rock } \\
\text { mass at the toe }\end{array}$ & $6 \%$ & \\
\hline Circular failure & $\begin{array}{l}\text { - Locally developed in extremely low strength highly } \\
\text { altered rock and/or near surface weathered rock }\end{array}$ & \multicolumn{2}{|c|}{$11 \%$} \\
\hline
\end{tabular}

Overwhelmingly, structurally controlled mechanisms dominate with $89 \%$ of failures by planar sliding or wedge failure, consisting of $69 \%$ wedge failures and $20 \%$ planar slides. Virtually all these mechanisms operate at the inter-ramp slope scale demonstrating the importance of higher order fault and shears in controlling slope design in contrast to the lesser role of smaller scale, joint dominated lower order defects. Examples of these mechanisms are shown in Figure 27. 

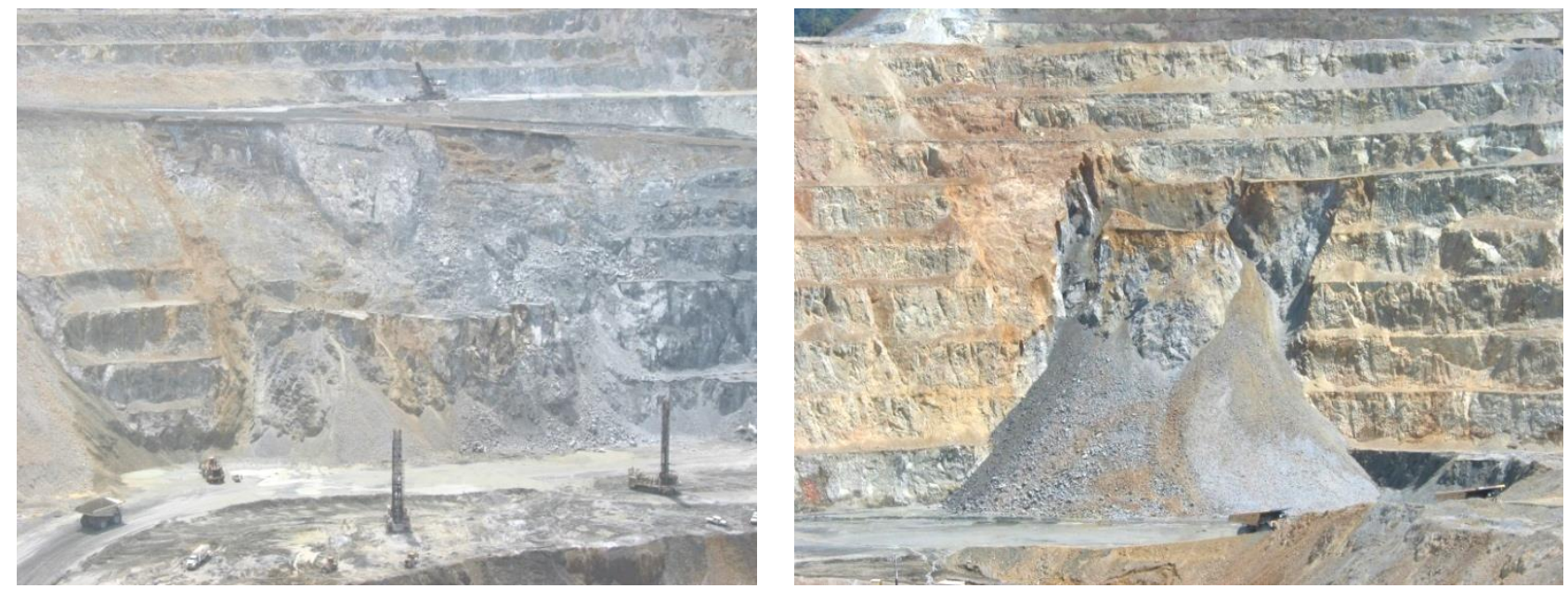

Figure 27 Examples of the structurally controlled slope movements dominating failure mechanisms in porphyry copper deposits

Analysis of the failure data shows a 'rose flower' structure pattern, with significant flattening of structures firstly radially out from the centre and secondly vertically. This controls a pattern of flattening with depth, which appears to increase outwards from the centre of mineralisation. This pattern may be a reflection of shearing generated by a stress system above a domical stock formed as part of the intrusion process as illustrated in Figure 18.

The larger scale failures can involve a complex interaction of structures whereby faults act as release surfaces on the flanks and at the rear while the middle of the failure geometry is controlled by either planar sliding, wedge failure, stepped path along joints and/or rock mass with a high structure influence. This composite-style of movement should be expected in a highly faulted and sheared rock mass typical of many porphyry copper deposits.

Of the $89 \%$ of failures involving structure, $66 \%$ include some sort of rock mass component along the failure path typical in a composite-style mechanism. So while structure is the clear primary control, rock mass condition is also a major contributor to controlling the mechanism of movement.

Only $11 \%$ of all the slope movements occurred by fully circular failure through the rock mass. The circular failures were concentrated in an extremely low strength rock mass unit, which has been significantly degraded by extensive alteration such that parts of the rock mass approach soil strength.

Rainfall was associated with $89 \%$ of all failures but only $2 \%$ appeared to be directly triggered by rainfall on the day of failure. Hence, antecedent rainfall seems to be the primary influence with the seven day rainfall total the critical factor. This demonstrates the importance of drainage measures as part of the total slope design package. Blasting was recorded as being associated with about $50 \%$ of all failures indicating the benefit of adopting good final limits blasting techniques.

\section{$5 \quad$ Summary and conclusions}

Engineering geological controls on the geotechnical model of porphyry copper-gold deposits can be grouped into:

- Regional to district-scale setting of the deposit and how this influences the distribution of lithologies, alteration and major structures and the linking of these in a geological history to understand the field relationships.

- Deposit-scale controls, in particular, brecciation, alteration, weathering and structure.

At the regional scale it is important to understand:

- The position of the deposit in the magmatic-volcanic arc/back-arc basin subduction system. 
- The distribution of any associated volcanic and/or sedimentary materials and how the regional picture can provide knowledge on the engineering geological condition of these materials.

- Uplift and erosional history of the district and how this helps predict the presence of important major geological features such as paleosurfaces and unconformities and the relatively distribution of geological units.

- The tectonic architecture of the related subduction system and how this influences district-scale structures in vicinity of the deposit.

This knowledge should be summarised into a geological history that explains all elements of the model making sure the field relationships between lithology and structure are adequately described.

At the deposit scale the primary objective of the geotechnical model is to unravel the engineering geological complexity typical of porphyry-style deposits and thereby highlight the important elements, which are likely to impact on slope stability for open pit design.

Within the complication of the porphyry geological model, features that should be investigated when building the engineering geological model include:

- Nature and occurrence of breccias.

- Alteration and weathering impacts on rock mass conditions.

- Location, orientation and nature of deposit scale structures.

Breccias are important in the engineering geological model as they often represent zones of relatively poorer quality rock. Description of breccias requires specific logging systems and classification for engineering purposes should be kept simple with a focus on engineering character and separation of volcanic, hydrothermal and tectonic breccia types.

The overall impact of alteration and weathering processes is change in rock mass quality compared with the original rock. This typically manifests as degradation in rock mass quality due to a reduction of the mechanical properties of the rock. In the high rainfall environment prevalent in Southeast Asia weathering can be an important feature of the rock mass model causing oxidation to significant depths. A relative ranking of rock mass quality approximates the vertical zonation of alteration typical in porphyry-style deposits whereby shallower alteration zones overprint and partly reconstitute deeper types. This telescoping generally results in a deterioration in rock mass quality with increased over-printing.

Structural modelling should focus on the hierarchy of structures to understand which defects will control stability at different slope scales. Models for feasibility studies that are substantially reliant on borehole data should adopt a confidence rating system to assist the prediction of which structures are likely to impact on slope stability.

Slope performance experience from operating mines in Southeast Asia strongly indicates that structurally controlled failure mechanisms dominantly regulate slope stability conditions usually at the inter-ramp slope scale. The larger mechanisms can involve a complex interaction of structures whereby faults act as release surfaces on the flanks and at the rear while the middle of the failure geometry is controlled by either structure and/or rock mass. So while structure is the clear primary control, rock mass condition is also a major contributor to controlling the style of movement. Antecedent rather than daily rainfall is a major influence on instability suggesting that drainage measures are an important component of the slope design.

The dominance of structure is an important conclusion as traditionally many geotechnical studies for pit slope design in porphyry-style deposits focus substantially on rock mass with little attention on evaluating structure. More attention is required in understanding the regional geological setting, how this influences district features and what the controls are on deposit-scale structural patterns. 


\section{Acknowledgement}

The assistance of Mark Fowler and Dylan Hemraj from PSM in helping to compile information used in this paper is gratefully acknowledged.

\section{References}

Aurelio, MA 2010, Structural geology and tectonics of the Boyongan - Bayugo copper-gold deposit, Surigao Mineral District, NE Mindanao - Part 2, internal report, Philex Mining Corporation, p. 19.

Berger, BR, Ayuso, RA, Wynn, JC \& Seal, RR 2008, Preliminary model of porphyry copper deposits, USGS Open File Report $2008-1321$. British Geological Survey 2007, Copper commodity profile, BGS Natural Environment Research Council, June.

Burg, JP 2015, Strike-slip and oblique-slip tectonics, http://www.files.ethz.ch/structuralgeology/jpb/files/English/5wrench.pdf

Burnham, CW 1985, 'Energy release in subvolcanic environments: Implications for breccia formation', Economic Geology, vol. 80, pp. 1515-1522.

Cammack, R 2016, 'Developing an engineering geological model in the fractured and brecciated rocks of a copper porphyry deposit', in MJ Eggers, JS Griffiths, S Parry \& MG Culshaw (eds), Developments in Engineering Geology, Geological Society, London, Engineering Geology Special Publication, no. 27, in press.

Cas, R, Giordano, G, Balsamo, F, Esposito, A \& Lo Mastro, S 2011, 'Hydrothermal breccia textures and processes: Lisca Bianca Islet, Panarea Volcano, Aeolian Islands, Italy', Economic Geology, vol. 106, pp. 437-450.

Corbett, GJ 2008, 'Influence of magmatic arc geothermal systems on porphyryepithermal Au-Cu-Ag exploration models: Terry Leach Symposium', Australian Institute of Geoscientists, bulletin 48, pp. 25-43.

Corbett, GJ \& Leach, TM 1997, 'Southwest Pacific Rim Gold-Copper Systems: structure, alteration and mineralisation', Short Course Manual, May 1997 edition.

Cruden, AR 1998, 'On the emplacement of tabular granites', Journal of the Geological Society of London, vol. 155, pp. 853-862.

Davis, GH \& Reynolds, SJ 1996, Structural geology of rocks and regions, second edition, John Wiley \& Sons, Inc., p. 776.

de Saint Blanquat, M, Tikoff, B, Teyssier, C \& Vigneresse, JL 1998, 'Transpressional kinematics and magmatic arcs', in RE Holdsworth, RA Strachan \& JF Dewey (eds), Continental Transpressional and Transtensional Tectonics, Geological Society of London Special Publications 135, pp. 327-340.

Hammarstrom, JM, Bookstrom, AA, Dicken, CL, Drenth, BJ, Ludington, S, Robinson Jr, GR, Setiabudi, BT, Sukserm, W, Sunuhadi, DN, Wah, AYS \& Zientek, ML with contributions from Cox, DP, Jarnyaharn, P, Kopi, G, Ngoc, NTM, Otarawanna, P, Pei, CS, Phany, U, Van Quy, Sakimoto, T, Saroa, D, Soares de Costa, N, Sotham, S, Sim, IM, Trung, NN, Wongsomasak, S, Yokarti, B \& Zaw, K 2013, Porphyry copper assessment of Southeast Asia and Melanesia, U.S. Geological Survey Scientific Investigations Report 2010-5090-D, p. 332.

Hammarstrom, JM, Bookstrom, AA, DeMarr, MW, Dicken, CL, Ludington, S, Robinson Jr, GR \& Zientek, ML with contributions from Cox, DP, Manipon, CJC, Rollan, LA, Sakimoto, T, Takagi, T \& Watanabe, Y 2014, Porphyry copper assessment of East and Southeast Asia-Philippines, Taiwan (Republic of China), Republic of Korea (South Korea), and Japan, U.S. Geological Survey Scientific Investigations Report 2010-5090-P, p. 241.

Hill, KC \& Hall, R 2003, 'Mesozoic-Cenozoic evolution of Australia's New Guinea margin in a west Pacific context', in RR Hillis \& RD Müller (eds), Evolution and dynamics of the Australian Plate, Geological Society of America Special Paper 372, pp. 265-290.

ISRM 1978, 'Suggested methods for the quantitative description of discontinuities in rock masses', International Journal of Rock Mechanics Mining Sciences and Geomechanics Abstracts, vol. 15, pp. 319-368.

Johnson, KM, Hammarstrom, JM, Zientek, ML \& Dicken, CL 2014, Estimate of undiscovered copper resources of the world, 2013, U.S. Geological Survey Fact Sheet 2014-3004, p. 3.

Lowell, JD 1968, 'Geology of the Kalamazoo orebody, San Manuel district, Arizona', Economic Geology, vol. 63, pp. 645-654.

Lowell, JD \& Guilbert, JM 1970, 'Lateral and vertical alteration-mineralization zoning in porphyry ore deposits', Economic Geology, vol. 65, pp. 373-408.

McMahon, BK, Douglas, DJ \& Burgess, PJ 1975, 'Engineering classification of sedimentary rocks in the Sydney area', Australian Geomechanics Journal, G5(1), pp. 51-53.

Middleton, C, Buenavista, A, Rohrlach, B, Gonzalez, J, Subang, L \& Moreno, G 2004, 'A geological review of the Tampakan copper-gold deposit, Southern Mindanao, Philippines', in Proceedings PACRIM 2004 Congress, Adelaide, pp. $173-187$.

Sapiie, B \& Cloos, M 2004, 'Strike-slip faulting in the core of the Central Range of West New Guinea-Ertsberg mining district, Indonesia', Geological Society of America Bulletin, vol. 116, pp. 277-293.

Sillitoe, RH 1985, 'Ore-related breccias in volcanoplutonic arcs', Economic Geology, vol. 80, pp. 1467-1514.

Sillitoe, RH 1994, 'Erosion and collapse of volcanoes: Causes of telescoping in intrusion-centered ore deposits', Geology, vol. 22, pp. 945-948.

Sillitoe, RH 2010, 'Porphyry copper systems', Economic Geology, vol. 105, pp. 3-41.

Stern, RJ 2010, 'The anatomy and ontogeny of modern intra-oceanic arc systems', in TM Kusky, M-G Zhai \& W Xiao (eds), The Evolving Continents: Understanding Processes of Continental Growth, Geological Society, London, Special Publications, 338, pp. 7-34.

Sullivan, TD 2010, 'The geological model', in AL Williams, GM Pinches, CY Chin, TJ McMorran, Cl Massey (eds), Geologically Active: Proceedings of the 11th Congress of the International Association for Engineering Geology and the Environment, CRC Press, London, pp. 155-170. 
Tosdal, RM \& Richards, JP 2001, 'Magmatic and structural controls on the development of porphyry Cu \pm Mo \pm Au deposits', Society of Economic Geologists, Reviews in Economic Geology, vol. 14, pp. 157-181.

USGS (US Geological Survey) 2016, Mineral Commodity Summaries, January.

$\mathrm{Wu}, \mathrm{JE}$, McClay, K, Whitehouse, P \& Dooley, T 2009, '4D analogue modelling of transtensional pull-apart basins', Marine and Petroleum Geology, vol. 26, pp. 1608-1623. 